\title{
ISSN 2500-3690
}
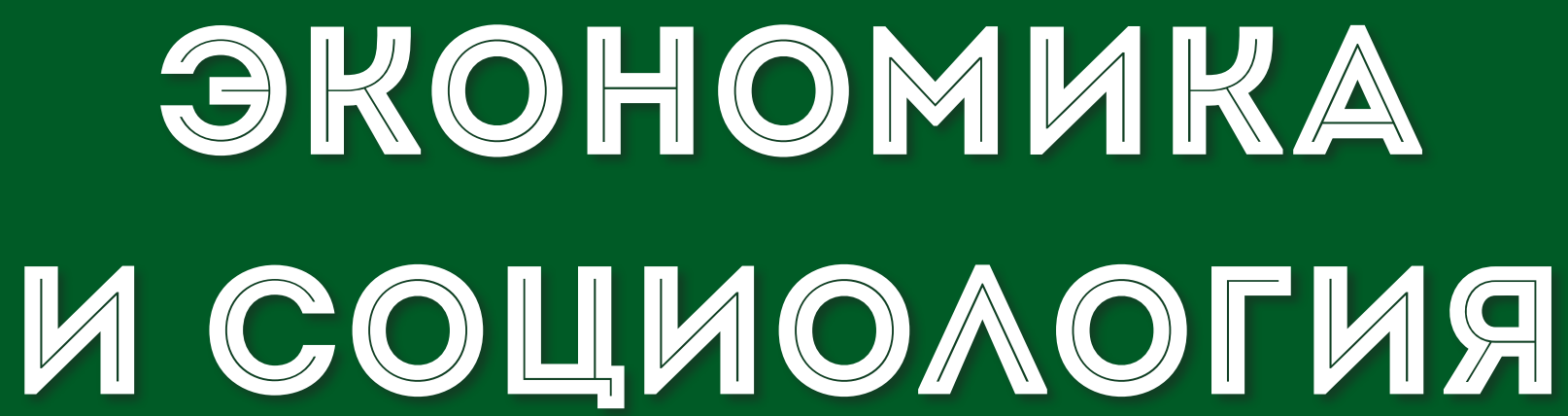

№3 (39)

2018 


\section{Редакционный совет:}

С.А. Барков - доктор социологических наук, профессор, заведующий кафедрой социологии организаций и менеджмента социологического факультета МГУ им. М.В. Ломоносова

А.Г. Зельднер - доктор экономических наук, профессор Института экономики Российской академии наук В.И. Зубков - доктор социологических наук, профессор Московского авиационного института (национальный исследовательский университет)

Н.П. Кетова - доктор экономических наук, профессор, заслуженный деятель науки РФ, заведующий кафедрой “Маркетинг и коммуникации в бизнесе” Южного федерального университета

О.Ю. Мамедов - доктор экономических наук, профессор Южного федерального университета

O.E. Рязанова - доктор экономических наук, профессор кафедры экономической теории Московского государственного института международных отношений (университета) Министерства иностранных дел Российской Федерации (МГИМО), главный редактор журнала «Экономика и социология»

С.Н. Сильвестров - доктор экономических наук, профессор, руководитель департамента мировой экономики и международных финансовых отношений Финансового университета при Правительстве РФ

\section{Главный редактор}

O.Е. Рязанова - доктор экономических наук, професcop

\section{Компьютерная правка и верстка А.С. Голубев}

\section{Редакционная коллегия:}

O.Е. Рязанова - доктор экономических наук, профессор кафедры экономической теории Московского государственного института международных отношений (университета) Министерства иностранных дел Российской Федерации (МГИМО), главный редактор журнала «Экономика и социология»

H.E. Фомина - доктор экономических наук, заместитель главного редактора журнала «Экономика и социология»

H.В. Авдошина - кандидат социологических наук, доцент, директор НИИ социальных технологий Самарского национального исследовательского университета им. академика С.П. Королева

С.А. Барков - доктор социологических наук, профессор, заведующий кафедрой социологии организаций и менеджмента социологического факультета МГУ им. М.В. Ломоносова

В.И. Зубков - доктор социологических наук, профессор Московского авиационного института (национальный исследовательский университет)

Н.П. Кетова - доктор экономических наук, профессор, заслуженный деятель науки РФ, заведующий кафедрой “Маркетинг и коммуникации в бизнесе” Южного федерального университета

Н.Ф. Тагирова - доктор исторических наук, профессор, заведующий кафедрой «Институциональная экономика и экономическая история» Самарского государственного экономического университета

Р.И. Хансевяров - доктор экономических наук, профессор Самарского государственного экономического университета

B.A. Савинова - доктор экономических наук, профессор кафедры финансов и кредита Самарского государственного экономического университета

Дата выхода издания 31.10.2018 г. Формат 60х84/8

Усл. печ. л. 7.79

Тираж 500 экз.

Отпечатано в типографии 000 «24 Принт»
Свидетельство о регистрации средства массовой информации: ПИ № ФС77-64819 от 2 февраля 2016 г.

Подписной индекс 80674 (Агентство «Роспечать») 

СОДЕРЖАНИЕ

социология

ТЕОРИЯ, МЕТОДОЛОГИЯ И ИСТОРИЯ СОЦИОЛОГИИ

Гюль Д.В. Турецкая социология: основные этапы развития

\section{СОЦИАЛЬНАЯ СТРУКТУРА, СОЦИАЛЬНЫЕ ИНСТИТУТЫ И ПРОЦЕССЫ}

Ходыкин А.В. Проблемы и перспективы развития труда в контексте перехода к зелёной экономике

\section{ЭКОНОМИКА. ЭКОНОМИЧЕСКИЕ НАУКИ}

\section{ЭКОНОМИЧЕСКАЯ ТЕОРИЯ}

Рязанова О.Е. Отношения собственности в социальной сфере: институциональный подход

Ермолаев К.Н. Методологическое значение марксистской концепии фиктивного капитала для анализа современной стадии развития глобального капитала ...

\section{ЭКОНОМИКА И УПРАВЛЕНИЕ НАРОДНЫМ ХОЗЯЙСТВОМ}

Плоткин Б.К., Сосунова Л.А. От материально-технического снабжения к логистике и обратно

Соболев Э.Н. Человеческий капитал в системе факторов оплаты труда квалифицированных работников

\section{ФИНАНСЫ, ДЕНЕЖНОЕ ОБРАЩЕНИЕ И КРЕДИТ}

Сорокина М.Г. Формирование динамических имитационных моделей финансовых механизмов конкурентного взаимодействия между банками на кредитном рынке

Борлакова T.E. Ипотечное жилищное кредитование: особенности формирования и развития 

социология

\section{ТЕОРИЯ, МЕТОДОЛОГИЯ И ИСТОРИЯ СОЦИОЛОГИИ}





\title{
ТУРЕЦКАЯ СОЦИОЛОГИЯ: ОСНОВНЫЕ ЭТАПЫ РАЗВИТИЯ
}

\author{
(c) 2018 Гюль Дарья Владимировна \\ кандидат исторических наук, доцент \\ доцент кафедры методологии социологических и маркетинговых исследований \\ Социологический факультет \\ Самарский национальный исследовательский университет им. академика С.П. Королева \\ 443011, Самара, улица Академика Павлова, 1 \\ E-mail: fisa-f@mail.ru
}

Статья посвящается истории развития социологии в Турции. Приводятся периодизации ведущих турецких социологов. Периоды анализируются в рамках системного подхода с точки зрения факторов, влияющих на развитие социологии. Приводятся основные события, являющиеся «поворотными точками» в истории развития науки, а также основные имена социологов и сферы их интересов.

Ключевые слова: история социологии, турецкая социология, история турецкой социологии, периоды развития турецкой социологии, турецкие социологи.

Как отметил один из крупнейших современных турецких социологов Эмре Конгар, «Академическая социология не успевает за всеми изменениями, происходящими в обществе» [1, c. 22]. Всего два года назад при исследовании факторов становления и развития социологии в Турции, образ турецких университетов и науки в Турции, в том числе, социологии, был совершенно не таким, как сегодня. Современные события еще раз подтверждают вывод о том, что политический фактор является основным в судьбе турецкой социологии [2]. 15-16 июля 2016 года в Турции произошла попытка военного переворота, вслед за которой последовали массовые увольнения госслужащих, преподавателей школ и университетов. Если отвлечемся от сложной ситуации, с которой столкнулась сегодняшняя Турция, и посмотрим, как развивалась социологическая наука в Турции с момента ее институционализации до сегодняшнего дня.

Э. Конгар выделил шесть этапов развития социологии в Турции:

1. 1923-1938 гг. Образование Турецкой республики и период правления М.К. Ататюрка.

2. 1938-1950 гг. Период Второй мировой войны и послевоенное время.

3. 1950-1960 гг. Правление Демократической партии до военного переворота.

4. 1960-1970 гг. Правление Комитета национального единства до укрепления позиций Партии Национального Порядка.

5. 1970-1983 гг. Кризис правления и политическая смута до 1983 г.
6. 1983-... [1, с. 13]. М.Д.Шахин выделяет еще ранний период развития [5, с. 11].

На наш взгляд, стоит уделить внимание периоду до 1923 года, так как в этом время происходит институционализация социологии как науки на территории тогда еще Османской Империи. В свете последних событий в Турции, целесообразно было бы «закрыть» шестой период 2016 годом, но пока остановимся на тех периодах, которые описаны в турецкой социологической литературе.

1910-1923 гг. Ранний (до-республиканский) период. Термин социология появляется в турецкой литературе в переводе книги французского социолога Селестина Бугле (Célestin Bouglé) «Что такое социальная наука?», сделанном М. Супхи в 1910 г. В 1910-1911 гг. Зия Гёкальп - знаковая фигура в социологии Турции впервые начал давать уроки социологии в школе Объединения и прогресса в Салониках. В университетскую программу социология впервые была включена в 1912 г. Первый социологический факультет в университете был открыт в 1914 г. на отделении литературы в Стамбуле. Во главе его встал 3. Гёкальп. В 1915 г. организован первый социологический институт Социологический Фонд, в 1917 г. начал издаваться журнал «Социологический сборник» (“İçtimaiyat Mecmuası”) c результатами исследований, проводимых этим институтом. В социологии интеллектуалы видели инструмент, с помощью которого можно решить проблемы молодой республики, поэтому турецкую модернизацию можно определить 
как «социо-политический и культурный проект, проводимый совместно политическими силами и социологией» [5, с. 11]. 3. Гёкальп разработал теоретическую социологическую программу, к которой очень часто за рекомендациями обращалась новая политическая власть. Такими плотными взаимоотношениями между политической властью и социологией можно объяснить характерное для этого периода стремительное принятие социологии как самостоятельной науки в академической, политической и интеллектуальной среде Турции.

1923-1938 гг. Период образования Турецкой республики и правления М.К. Ататюрка. Определяющей особенностью этого периода было то, что во главе с 3. Гёкальпом мыслители поставили перед собой цель познакомить общество с социологией и заложить научные основы нового, более совершенного, общества. После смерти 3. Гёкальпа в 1924 г. последователи продолжили его путь. Х. Сабит, М. Шереф, Т. Альп, Н. Садак, Ф. Кёпрюлю были мыслителями, на которых он оказал большое влияние. Основными идеями, которые развивал 3. Гёкальп, были идеи национализма, модернизации, тюркизации, позитивизма, солидарности, эволюционизма с опорой на знание, называемое социологией.

Наука об обществе, которую рассматривали как средство спасения Империи, состояла не только из имени 3. Гёкальпа и его последователей. Вокруг журнала «Dergah» (Дэргях) образовалась другая группа мыслителей, верящих в идеологию национализма. Внутри этой группы главную роль играли М.Ш. Тунч, И.Х.Балтаджыоолу, плюралисты, не разделяющие идеи детерминизма, отстаивающие идею индивидуализма. В этом же ряду можно перечислить Я. Кадри, М.Э.Эриширгиль и других мыслителей. Стоит упомянуть и Шефик Хюсню с журналом «Aydınlık» (Айлынлык - свет), которым он руководил. Влияние этих журналов прослеживается в политической научной среде даже в наши дни.

Многие политики-бюрократы, окружая себя талантами, занимались идеологией. Работа М.Э. Бозкурта типичная «про-Ататюркская» книга. В этой книге отстаивается светский республиканский устрой. Такие мыслители как Ю. Акчураоолу, А. Ааоолу ставили идею Тюркизма в качестве стержня, вокруг которого должен происходить процесс оформления нового общества.

Одним из важнейших течений периода были взгляды мыслителей, собравшихся вокруг журнала «Кадро». Ш. Сюрейя, В. Недим, И. Хюшрев, Б. Асаф, Ш. Язман и Я. Кадри - основной их целью было создать теорию Кемалистского периода. Основы развиваемой в наши дни мир-системной теории такими исследователями как Э. Аргири, С. Амин, И. Валлерстайн были заложены еще в 1930 гг. создателями «Кадро», но с причислением Якуба Кадри к «тиранам» был положен конец их публикационной деятельности. Направление «Кадро» проявило себя с некоторыми изменениями в более поздние годы в турецкой политической жизни как направление «Революция».

Характеристика этого периода - рассмотрение вопросов на теоретическом уровне, обсуждение тем и вопросов в форме взаимопроникновения политики, философии, образования и идеологии. Мы встречаем широкий спектр различных идей, теорий, концепций. Поэтому «было бы правильнее говорить не о развитии социологической мысли в этот период, а о развитии турецких идей» [1, с. 14]. Влияние западных теорий на турецких мыслителей огромно. Данный период для всех мыслящих людей был периодом поиска и создания «нового общества», «нового общественного сознания». Многие теоретические вопросы становились предметом споров. Для социологии в Турции это был период относительной демократии.

1938-1950 гг. Период Второй мировой войны и послевоенное время. Это период интенсивных исследований и на микро- и на макроуровнях. Изучаются вопросы участия страны во Второй мировой войне, ведутся разнообразные эмпирические исследования. Во главе организаций становятся университеты - генераторы идей, проводящие независимые исследования. Журналы тоже стали площадкой, на которой обсуждались, дискутировались и защищались разные идеи. После Второй мировой войны окрепли демократические и левые веяния. Тем временем, Исмет Паша принял решение перейти к двухпартийной демократии. Его целью было, с одной стороны, создать настоящую оппозицию, с другой стороны, подавить «вредные мысли», да так, чтобы даже эта оппозиция не смогла их поддержать. В результате многие ученые, имена которых известны в мировой социальной науке, были вынуждены переехать за границу. Развитие турецкой социологии приостановилось на 15-20 лет. Уехавшие за рубеж исследователи же 
М. Шериф, Н. Беркес, сделали вклад в мировую науку. Самый важный вклад в социологию 1940х годов внесли полевые исследования, особенно исследования турецкой деревни. После проведенных «чисток», Турция вернулась к полевым эмпирическим исследованиям в полной мере только 20 лет спустя, в 1965 гг.

1950-1960 гг. Правление Демократической партии до военного переворота. Практически полностью бесплодный период. Демократическая партия, создающая впечатление либерализма, по сути, осуществляла авторитарное управление. Репрессии стали определяющей особенностью этого периода. Власть была нетерпима к любым проявлениям свободомыслия. Возможность производить научное знание отсутствовала. Например, за фразу «Не давайте щербет исходя из пульса» (не держите нос по ветру, не подстраивайтесь под других), произнесенную на лекции, профессор был уволен со своей должности $[1$, с. 16]. Социология переживала не только застой, но и откат назад. Но, хотя после 1940 гг. работы и не имели возможности для публикации, они проводились, в том числе и в 50-60 гг. В этот период были опубликованы некоторые теоретические работы, например, «Проблемы социологии» Хильми Зия в 1955 г.

1960-1970 гг. Правление Комитета национального единства до укрепления позиций Партии Национального Порядка. Когда пал запрещающий все репрессивный режим, который подавлял даже самые правые, либеральные идеи запада, результаты сразу стали видны. В Стамбуле на факультете литературы Ж. Таньол, на экономическом факультете Д. О. Тютенгиль, в Анкаре на факультете политических наук И. Яса, в Средне-Восточном техническом университете М.Б. Кырай начали активно проводить теоретические и эмпирические исследования. В середине 1960-х гг. было организовано Общество Турецких социальных наук в г. Измир. Начали проводиться городские исследования, было опубликовано несколько книг по введению в общественные науки. В рамках профессионального сообщества активно шел обмен мнениями, сбор данных. Ш. Мардин, М. Кырай, Р. Келеш, Д. Герай, О. Ары, Э. Озбудун, Д. Байкал, М. Тунчай, Ш. Уйсал, Ч. Кяытчыбашы участвовали в этом масштабном проекте. Часть исследований не получилось завершить по ряду причин. Но «Религия и идеология» Ш. Мардина, «Психологические грани социальных изменений» Ч. Кяытчыбашы,
«Обмен сообщениями в Измире» О.Ары., «Город, который не смог организоваться» М. Кырая, «Кварталы Измира» Р. Келеша, «Городская семья в Измире» Э. Конгара, были доведены до результата и опубликованы. В 1966-1968 гг. Общество турецких социальных наук выпустило сериал «Введение в социальные науки». Среди теоретических работ этого периода «Человек и культура» Гювенчина, «Модернизация и бюрократия» Хепера, «Человек и люди» Ч. Кяытчибашы, «Основы социологии города» Р. Келеша, «Введение в социальную работу» Э. Конгара, «Идеология» Ш. Мардина и др.

Ключевым моментом стал семинар, проведенный совместно Обществом турецких социальных наук и Институтом исследований населения Хаджеттэпэ 23-25 Февраля 1970 г. По его результатам издали книгу «Развитие социальных исследований в Турции». Темы, поднимаемые в этом семинаре: общественные изменения, исследования в обществознании и социальной психологии, в политической науке, в социальной и культурной антропологии, методология полевых исследований, связь теории и понятий, исследовательские техники, использование результатов исследований и проблемы исследований в Турции. На этом семинаре были представители почти всех университетов Турции (Кырай, Кёсемихаль, Саран, Ары, Мардин, Туная, Паяслыоолу). Особое значение имел манифест, опубликованный после семинара. Пятым пунктом в нем провозглашалась необходимость создания со стороны государства независимой организации социальных исследований для поддержки проведения исследований, обеспечения сотрудничества между исследователями. Призывалось отдавать приоритет социальным исследованиям, которые «помогут подъему нашей страны и решению социальных проблем нашего общества» [1, с. 18].

В 1961 г. в Турции утвержден западный тип Конституции, привнесший определенные свободы. Следствием был выход социальных исследований за пределы университетов. Пока университеты еще не перестроились после репрессивного периода, за их границами начали проводиться интересные исследования. Типичные их примеры - произведения Доан Авджиоолу и Исмаила Джэма. Образование Организации государственного планирования, которая предоставила собранные данные в пользование ученых, обеспечило хорошую поддержку, осо- 
бенно на уровне макро- исследований.

1970-1983 гг. Кризис правления и политическая смута. На социологию политические волнения оказали сильное воздействие, что затормозило ее развитие. Но такой катастрофической ситуации, как в 1947 г., не произошло. Этому способствовало, в частности, то, что политическая ситуация стала налаживаться через 2 года. Тем не менее, значительная часть ученых из Анкары переехала либо за границу, либо в Стамбул. В Стамбуле образовался новый центр общественных наук Университет Боазичи. K 1980 гг. в Стамбуле, Анкаре, Эскишехире Академии Экономических и Торговых наук находились в руках молодых руководителей, наблюдается развитие разных направлений социологии. Увеличилась численная потребность в социологах, выросло производство знания в этой области. Период, начавшийся с застоя, закончился переходом на новую ступень.

1983 г. по настоящее время. Социология занимает прочные позиции. Наука достигла уровня, когда она не зависит от политических волнений. Производство теоретического и прикладного знания поддерживают друг друга. Социология не ограничена только университетами. Уважаемые исследователи проводят научные исследования самостоятельно и публикуют их данные. Исследования, которые проводятся в университетах, закладываются в основу обучения, публикуются потом вне стен университетов. Социология сблизилась с обществом. 6-8 Июня 1980 г. в Анкаре состоялся Первый Национальный конгресс социальных наук. На обсуждение было вынесено 59 тем. Методология, городская социология, бюрократия, политическая социология, социология медицины, история, психология и социальная психология, экономика и общество, социология села и т.д. Даже по мировым стандартам конгресс состоялся на довольно высоком уровне. Постепенно социология начала выходить за рамки только крупных городов Турции: Эрзурум, Эскишехир тоже стали центрами социологических исследований. Еще одним фактором развития стали премии в области социологии по конкурсам, спонсируемым банками, газетами, частными и общественными организациями.

Итак, «поворотными моментами», определяющими границы периодов развития турецкой социологии всегда были политические события. Политика и социология в Турции тесно связаны, на ранних этапах ее развития политическая власть рассматривает социологию как инструмент воздействия. Постепенно социология пытается отдалиться от политики, отвоевывая право проводить независимые исследования, но если политическая власть не видит в социологии друга, то начинает видеть врага. Профессор Университета «Ататюрк», доктор наук Йылдыз Акполат так описывает положение социологии в обществе: «В Турции проблемы гражданского общества даже не имеют возможности быть обсуждаемыми. Единственная наша реальность - это политика. Если социологи начинают интересоваться гражданским обществом, их исследования либо запрещаются со стороны политических сил, или, что еще хуже, к ним начинают применять внутреннюю цензуру... К какой стороне мы бы ни примкнули, результат один: в Турции не создана и не создается социология как наука о турецком гражданском обществе... Так как общество не отделено от государства, турецкая социология очень уж любит политику... Однако, такая погруженность в политику, замалчивание страданий гражданского общества... внутренняя цензура, жестокость по отношению к научному сообществу, увеличение числа назначений академических кадров, снижение мотивации, занятие наукой не из-за любви к ней, а за деньги, часами на уроках растрачивание своей жизни, снижение качества студентов день ото дня...и, что самое главное, зажатость между глобальностью и локальностью стоят перед нами как основные проблемы турецкой социологии» [6, c. 7].

\section{Библиографический список}

1. Emre Kongar (2012) Türk Toplum Bilimcileri 1-2. Remzi Kitabevi A.Ş. 1078s.

2. Гюль Д.В. Турецкая социология: детерминирующие факторы возникновения и развития социологии в Турции//Экономика и социология. - № 2 (30). - 2016 г. - с. 7-12.

3. РБК. Военный переворот в Турции, 11 авг. 2016,- https://www.rbc.ru/rbcfreenews/57ac391f9a79472b4c0d6fdf ?from=newsfeed - дата последнего обращения 04.10.2018 г. 
4. Интернет-издание «МК-Турция». В Турции сотрудники закрытого университета приговорены к тюремным срокам за связи с Гюленом.- 03 апреля 2018.- http://mk-turkey.ru/politics/2018/04/03/v-turcii-sotrudnikizakrytogo.html - дата последнего обращения 04.10.2018 г.

5. Mehmet Cem ŞAHİN Türk sosyolojisinin kısa tarihi: dönemler, şahıslar ve ana yönelimler İslâmî İlİmler Dergisi, yıl 12 cilt 12 sayı 1 Bahar 2017 s.7-41

6. Yıldız Akpolat Türk sosyolojisi üzerine kısa bir bakış // Sosyoloji konferansları._ no: 53 (2016-1).-s.3-27.

Поступила в редакциию 07.10.2018 

социология

\section{СОЦИАЛЬНАЯ СТРУКТУРА, СОЦИАЛЬНЫЕ ИНСТИТУТЫ И ПРОЦЕССЫ}





\title{
ПРОБЛЕМЫ И ПЕРСПЕКТИВЫ РАЗВИТИЯ ТРУДА В КОНТЕКСТЕ ПЕРЕХОДА К ЗЕЛЁНОЙ ЭКОНОМИКЕ
}

\author{
(C) 2018 Ходыкин Александр Владимирович \\ Самарский национальный исследовательский университет им. академика С.П. Королева \\ 443011, Самара, улица Академика Павлова, 1 \\ E-mail: avhod@yandex.ru
}

В работе исследованы экологические, экономические и социальные аспекты заявленного на международном уровне глобального перехода к зелёной экономике. На базе международных документов проанализированы проблемы и перспективы развития трудовой сферы в контексте глобального перехода к зелёной экономике.

Ключевые слова: зелёная экономика, рынок труда, экология, развитие, проблемы, перспективы, международное сообщество, зелёное рабочее место.

Рост производственных мощностей и безграничность потребностей человека в сочетании с ограниченностью ресурсов планеты способствуют ухудшению экологической ситуации на Земле и развитию глобального экологического кризиса. Так, согласно данным отчёта Всемирного фонда природы за 2010 год, значение индекса живой планеты, оценивающего богатство биоразнообразия, упало на $30 \%$ по сравнению с 1970 годом [1]. В то же время потребность человечества в природных ресурсах с 1966 года увеличилась почти в 2 раза [2]. По данным Международного энергетического агентства за 2016 год, ежедневно в мире 18 миллионов человек умирают по причинам, связанным с загрязнением воздуха [3]. В такой ситуации значимым ресурсом для улучшения экологической ситуации на Земле становится переход на зелёную экономику. Решение о глобальном переходе на зелёную экономику на мировом уровне было принято ещё в 2010 году на 40 Всемирном экономическом форуме в Давосе.

Зелёная экономика - это экономическая система, основанная на комплексном сочетании в хозяйственной деятельности человека принципов ресурсосбережения и бережного отношения к природе, соблюдения связанных с трудовой деятельностью прав человека и повышения экономической эффективности деятельности. Зелёная экономика предполагает необходимость создания зелёных рабочих мест. В Докладе МОТ за 2008 год термин «зелёное рабочее место» определяется как место работы в промышленности, сельском хозяйстве, в научно-исследовательской или административной деятельности, предполагающее работу, способствующую сохранению или восстановлению окружающей среды [4]. Российские экономисты Е.А. Войкина и И.М. Потравный выделяют следующие критерии зелёных рабочих мест: экономические (достойная зарплата работников, высокий уровень производительности труда, низкая материалоёмкость), социальные (социальная защита и соблюдение трудовых прав работников), технические и технологические (отсутствие вредных и опасных условий труда, использование современного оборудования), экологические (минимизация отрицательного воздействия на окружающую среду) [5].

Перспективы развития труда в рамках перехода к зелёной экономике представлены в докладе МОТ от 2018 года, авторы которого предсказали, что переход к зелёной экономике позволит создать 24 миллиона новых рабочих мест к 2030 году, в то время как упразднено будет лишь 6 миллионов рабочих мест [6]. При этом необходимо отметить, что качество создаваемых рабочих мест будет значительно выше качества упраздняемых. Создание новых рабочих мест призвано обеспечить кадрами такие ключевые для формирования зелёной экономики процессы, как переход от углеводородов к альтернативным источникам энергетики; создание, развитие и восстановление экосистем; очистка воздуха, воды, почв; совершенствование ведения сельского и лесного хозяйства, туризма и промышленности.

Однако несмотря на всю свою перспективность переход к зелёной экономике сопряжён и с рядом проблем, решение которых определит его эффективность и способность достичь поставленных целей. 
Во-первых, как правильно отмечает П.В.Трифонов, на сегодняшний день многие виды работ, которые должны стать зелёными, по факту к таковым отнести нельзя из-за их несоответствия ни экологическим, ни экономическим, ни социальным требованиям к зелёным рабочим местам. Взять, к примеру, деятельность по переработке отходов. В принципе это должна быть типичная зелёная деятельность, однако на практике она часто бывает сопряжена с загрязнением окружающей среды, вредным и опасным для рабочих трудом, который к тому же крайне плохо оплачивается [7]. Необходимым условием решения данной проблемы является совместная деятельность по охране труда и охране окружающей среды со стороны международных организаций, государственных органов, законодательных институтов, общественных организаций и институтов гражданского общества. Особенно такая деятельность необходима в слабо развитых и развивающихся странах.

Во-вторых, чтобы приобрести глобальный масштаб, переход к зелёной экономике должен состояться в максимальном количестве стран и затронуть максимальное количество людей во всём мире, однако таких стран и количества, вовлечённых в зелёную экономику людей по всему миру в настоящее время явно недостаточно. Отставание слаборазвитых и развивающихся стран, как в экологическом, так и в экономическом и социальном плане всё ещё слишком велико для их перехода к зелёной экономике. Экономика таких стран основывается на низкоэффективном производстве, загрязняющем природу и не дающем возможностей для развития, как экономики, так и занятых в ней людей, в результате чего достичь глобального распространения достойных условий труда пока не удаётся. Что касается развития человека, то имеется значительное отставание слаборазвитых стран по этому показателю. Так, значения индекса развития человеческого потенциала (ИРЧП), варьирующиеся от 0 до 1, в наиболее и наименее развитых странах различаются почти в 3 раза [8]. Примерно такой же разрыв между развитыми и неразвитыми странами остаётся по индексу экологической эффективности [9]. Затрудняет переход к зелёной экономике и высокий уровень глобального социально-экономического неравенства между людьми, ставшего следствием широкого распространения рабочих мест с низкой оплатой труда на фоне стремительно возросших доходов наиболее богатой части населения. По данным исследований ООН (исследовались 166 стран, в которых проживает 97\% населения Земли) уровень глобального социально-экономического неравенства с 1970-х до середины 2000-х годов значительно вырос, а после середины 2000-х не снижается и остаётся на стабильно высоком уровне [10]. Актуальной остаётся проблема гендерного неравенства: среднемировое значение индекса гендерного неравенства (ИГН) составляет 0,441 [11]. Это означает, что из-за связанных с гендерным неравенством проблем в среднем в мире не используется около 44\% человеческого потенциала. Учитывая вышесказанное, можно заключить, что сокращение различных форм ресурсного неравенства и содействие в развитии отстающим странам является важным условием формирования глобальной зелёной экономики. Проблема избыточного неравенства в различных его видах остаётся труднопреодолимым препятствием для достижения составляющих ядро зелёной экономики экологических, экономических и социальных целей, как на уровне отдельных государств, так и на международном уровне.

В-третьих, особо актуальной остаётся проблема экспорта наиболее неэкологичных и загрязняющих окружающую среду видов производства из развитых стран в слаборазвитые. На то есть две основные причины:

- во-первых, затраты на рабочую силу в слаборазвитых странах в разы ниже, т.к. там можно платить более низкую зарплату и не тратиться на обеспечение достойных условий труда для работников;

- во-вторых, в слаборазвитых странах значительно ниже требования $\mathrm{K}$ экологичности производства, что позволяет его владельцам экономить на обеспечении соответствия производства строгим экологическим стандартам развитых стран. В результате привлечь к ответственности разрушающих природу и нарушающих права человека владельцев производства по законам развитых стран не получается.

Для решения этой проблемы необходимо совершенствование системы международного права и правоприменительной практики, а именно создание единых международных экологических стандартов и стандартов достойного труда и разработка механизмов их реализации в любой точке мира. Государства должны получить право привлекать к ответственности своих 
граждан за их деятельность в любой точке мира, а международному сообществу необходимы рычаги давления на страны, пренебрегающие этим правом в отношении лиц, нарушающих экологические стандарты и права человека. В отношении корпораций, нарушающих экологические стандарты и права человека, должны активно применяться международные санкции.

Развитие и распространение экологичных технологий сдерживается их высокой стоимостью и недостаточным уровнем инвестиций в их разработку и распространение. Особенно сильно эта проблема проявляется на этапе разработки и начального внедрения новой экологичной технологии, т.е. на этапах, когда она пока ещё дорого стоит и представляется экономически невыгодной. Кроме того, для представителей крупного бизнеса, работающего в сфере неэкологичных технологий, не выгодно развитие более экологичной промышленности, которая потенциально более конкурентоспособна, и они в лучшем случае не будут инвестировать в ресурсосберегающие технологии, а в худшем могут препятствовать их развитию. Для повышения инвестиционной привлекательности экологичных технологий целесообразно сочетание административных мер (к примеру, ужесточение наказаний за превышающее нормы по загрязнению окружающей среды производство) с мерами экономического стимулирования (например, повышение налоговой нагрузки на углеводородную энергетику с использованием полученных средств для финансирования ресурсосберегающих проектов).

Несмотря на все представленные выше проблемы перехода к зелёной экономике, завершить их анализ можно всё же на оптимистичной ноте: мы можем констатировать, хоть и не такое значительное, как нам хотелось бы, но всё же улучшение значения большинства проблемных показателей за последние годы. Снижается количество стран с низким развитием человеческого потенциала, уменьшается гендерное неравенство, растёт доля возобновляемых источников в мировом энергопотреблении [12]. Однако мы должны понимать, что для достижения целей глобального перехода на зелёную экономику этого явно не достаточно. Глобальный переход к зелёной экономике должен стать исходным скачком на новый уровень природопользования, хозяйственной деятельности и социальной сферы. Поэтому предстоит ещё очень много сделать для улучшения экологических, экономических и социальных показателей развития человечества.

\section{Библиографический список}

1. Living Planet Report / Доклад Всемирного фонда природы о Живой планете. - 2010. [Электронный ресурс]. URL: http://www.wwf.ru/recources/publ/book/436 (дата обращения: 10.10.2018).

2. Захарова T.В. «Зелёная» экономика как новый курс развития: глобальный и региональный аспекты // Вестник Томского гос. ун-та. Экономика. 2011. С. 28-38.

3. Energy and Air Pollution: World Energy Outlook Special Report.Paris. - 2016. [Electronic resource].-URL: www.iea. org/publications/freepublications/publication/WorldEnergyOutlookSpecial Report2016EnergyandAirPollution. pdf (Accessed 10.10.2018).

4. Green Jobs: Towards decent work in a sustainable, low-carbon world. UNEP, ILO, OIE, ITUC, 2008. - 2008. [Electronic resource].- URL: http://www.ilo.org/wcmsp5/groups/public/--ed_emp/--emp_ent/documents/publication/wcms_158727.pdf (Accessed 07.10.2018).

5. Войкина Е. А., Потравный И.М. Зеленая занятость и рынок труда при формировании экологически ориентированной экономики // Вестник Санкт-Петербургского университета. Экономика. - 2018. Т. 34. Вып.2. C. 217-240. - 2018. [Электронный ресурс]. - URL: https://doi.org/10.21638/11701/spbu05.2018.202 (дата обращения: 07.10.2018).

6. World Employment and Social Outlook 2018: Greening with jobs.- 2018. [Electronic resource].- URL: https://www.ilo.org/wcmsp5/groups/public/--dgreports/--dcomm/--publ/documents/publication/ wcms_628654.pdf (Accessed 07.10.2018).

7. Трифонов П.В. Зелёные рабочие места - основа эколого-ориентированной экономики в XXI веке // Стратегии бизнеса. -2015 . № 3. С. 21-27.

8. Human Development Indices and Indicators. Special Report. - 2018. [Electronic resource]. - URL: http://hdr.undp. org/sites/default/files/2018_human_development_statistical_update.pdf (Accessed 07.10.2018).

9. Рейтинг стран мира по рейтингу экологической эффективности: Yale Center for Environmental Law and Policy: The Environmental Performance Index 2018. - 2018. [Электронный ресурc]. - URL: https://gtmarket.ru/ ratings/environmental-performance-index (дата обращения: 07.10.2018). 
10. Обзор мирового экономического и социального положения, 2014 год: сокращение неравенства в интересах устойчивого развития. - 2014. [Электронный ресурс]. - URL: http://www.un.org/en/development/desa/policy/ wess/wess_archive/2014wess_overview_ru.pdf (дата обращения: 10.10.2018).

11. Статистические данные ООН: Gender Inequality Index. - 2018. [Электронный ресурс]. - URL: http://hdr.undp. org/en/composite/GII (дата обращения: 07.10.2018).

12. О возобновляемых источниках в производстве электроэнергии.- 2018. [Электронный pecypc].- URL: https://ecotechnica.com.ua/energy/3349-dolya-vie-v-proizvodstve-elektroenergii-v-mire-dostigla-25.html (дата обращения: 07.10.2018). 
ЭКОНОМИКА. ЭКОНОМИЧЕСКИЕ НАУКИ

\section{ЭКОНОМИЧЕСКАЯ ТЕОРИЯ}





\title{
ОТНОШЕНИЯ СОБСТВЕННОСТИ В СОЦИАЛЬНОЙ СФЕРЕ: ИНСТИТУЦИОНАЛЬНЫЙ ПОДХОД
}

\author{
(c) 2018 Рязанова Олеся Евгеньевна \\ доктор экономических наук, профессор, заведующая кафедрой «Экономическая теория» \\ Московский государственный институт международных отношений (университет) \\ Министерства иностранных дел Российской Федерации (МГИМО) \\ 119454, г. Москва, проспект Вернадского, 76 \\ E-mail: kafedra4006@mail.ru
}

В статье отмечается, что в современной науке происходит расширение границ содержания «института собственности». Выдвинув тезис о том, что социальные блага могут рассматриваться как «абстрактное имущество», которое не может быть объектом реального физического обладания, но сводимо к денежной оценке, доказывается, что им можно пользоваться и распоряжаться. Показано, что в отношениях собственности в социальной сфере можно выделить благо обладания в целью извлечения пользы из «владения» социальными благами и бремя содержания в смысле расходов на сохранение своего «владения» и защиту его от третьих лиц. Сделано заключение о том, что отношения собственности трансакционного типа с экономической точки зрения могут появляться через правовые формы, т.е. возможно существование прав собственности на социальные блага. В связи с тем, что социальные блага могут быто предметом отчуждения-присвоения, выдвинута гипотеза о существовании первичных и производных отношений собственности в социальной сфере.

Ключевые слова: отношения собственности, социальная сфера, правомочия собственности, социальные блага, трансакции, трансакционные издержки

В современном обществе наблюдается возрастание роли неэкономических, социальных факторов в экономической жизни. Если сравнивать классическую политическую экономию, которая изучала материализованные экономические отношения, то современная экономическая теория все больше внимания уделяет социальным отношениям и их влиянию на экономические процессы. Растет значение неформальных институтов по сравнению с формальными [3]. Трансформация происходит и с дефиницией «собственность», которая все больше выходит за рамки узконаучной трактовки одной сферы человеческого знания и превращается в межсекторальное понятие. Если раньше категория «собственность» изучалась в рамках экономической и юридических наук [4], то сейчас она является одной из центральных категорий всех общественных наук. Поэтому появилась необходимость выработки синтезированного понимания собственности как полиэдрической (многогранной) категории, включающей различные аспекты общественных отношений.

Любые отношения собственности проявляются во взаимосвязи объекта и субъекта. В качестве объекта отношений собственности в социальной сфере выступают не вещи, ресурсы, продукты интеллектуального труда, как в сфере материального производства, так и нематериального производства. Здесь объект специфичен, а именно это некие правомочия, свободы, функции, действия, которые могут быть объектом отчуждения-присвоения, осуществляемых посредством трансакций, поскольку именно трансакции представляют собой процесс обмена правами и свободами. Понятие социального блага как социологическая категория выражает все то, что реально соответствует объективным, естественным потребностям человеческого бытия, удовлетворение которых создает необходимые условия для его поступательного развития. Однако существуют элементарные, первостепенной жизненной значимости основы человеческого бытия, без которых бытие вообще невозможно и в конститутивном закреплении которых право играет генерирующую, судьбоносную роль. Социальные блага, закрепленные правом, приобретают нормативную значимость, общеправовую ценность, гарантированную охрану и защиту. Экономическое содержание этих объектов составляют трансакционные издержки. Они не имеют прямого или косвенного экономического результата, а проявляются путем повышения эффективности других явлений и 
процессов общества. Социальные блага как объекты отношений собственности связаны с продуктами социального труда, возникающими в процессе взаимодействия между людьми (государством, законодательством, гражданским обществом, политикой, сделками и др.), что также определяет их специфику.

Субъектами отношений собственности в социальной сфере являются экономические агенты, между которыми возникают отношения по поводу отчуждения-присвоения правомочий, свобод, функций и т.п. Таким образом, специфичность отношений собственности в социальной сфере проявляется в том, что это экономические отношения между агентами по поводу присвоения-отчуждения социальных благ (правомочие, привилегия, функция, свобода, действие, административный ресурс), которые непосредственно связаны с продуктами социального труда как проявление биосоциальной сущности человека.

Теперь возникает вопрос, могут ли эти отношения проявляться через правовые формы, т.е. могут ли существовать права собственности на объекты этих отношений: свободы, функции, правомочия, существуют ли права на правомочия, свободы, функции с экономической точки зрения? С юридической точки зрения - нет, т.к. в соответствие с ч.I раздел II ГК РФ объектом права собственности может быть только имущество, в том числе деньги, ценные бумаги, права на вещи [1]. Исходя из экономической и юридической теорий прав собственности содержание собственности включает три основных правомочия: владеть, пользоваться, распоряжаться с целью извлечения из объекта собственности определенных выгод и доходов. Р. Коуз, А. Алчиан добавили еще ряд прав: на доход, суверена, безопасность, передачу в наследство и т.д. Отсюда любое благо, способное приносить пользу, доход может быть объектом прав собственности. Это, хотя и специфично, но относится и к социальным благам, в отношении которых различные субъекты в трансакционной сфере обладают «пучками» прав собственности. Право владение в социальной сфере носит абстрактный характер. Например, право на выдачу льготного кредита, которое зависит только от желания «собственника» этого права, например, чиновника властной структуры или органа [3]. Но правомочия пользования и распоряжения социальными благами в трансакционной сфере налицо. Пользование как раз и означает извлечение для собственника выгоды или дохода (в нашем примере ренты чиновнику за предоставление льготного кредита). Распоряжение социальных благ осуществляется путем из отчуждения-присвоения в ходе трансакций на основе добровольного соглашения сторон. Владелец такого блага сам решает, вступать ему в обмен правомочиями или нет. Таким образом, в отношении социальных благ также применимы «пучки» прав собственности. С юридической стороны некоторые социальные блага, прежде всего правомочия, возникающие из обязательств, являются обязательными правами, но они не могут быть объектами права собственности и иных вещных прав, поскольку де-юре в собственности может находиться только имущество (ГК РФ Ч. 1., Гл. 13, ст. 209) [1]. Более того, в большинстве случаев реализация этих правомочий незаконна (например, чиновники юридически осуществляют государственные функции, которые нельзя использовать для личной выгоды). Но с экономической точки зрения властное управленческое полномочие и любое социальное благо - это такой же источник получения дохода, как и земля, деньги, ценности и иное имущество.

Таким образом, подводя итог выше сказанному, социальные блага - правомочия, функции, свободы можно рассматривать как некое «абстрактное имущество», которое не может быть объектом реального физического обладания и владеть им можно только абстрактно, мысленно. Но «абстрактное имущество», как и физическое, может сводиться к денежной оценке и приносить прямой доход или пользу, т.е. выполнять функцию пользования. «Абстрактным имуществом» можно распоряжаться, причем, если при распоряжении физическим имуществом осуществляется физический обмен, то распоряжение «абстрактного имущества» осуществляется посредством правового обмена, т.е. трансакции.

В экономической теории в содержании отношения собственности выделяют две стороны: обладание имуществом и бремя его содержания, включая риск его порчи, утраты. Это свойственно и отношениям собственности в социальной сфере. Что касается первой стороны, то речь идет об установлении собственником полного хозяйственного господства над принадлежащим ему социальным благом. Но обратной стороной отношений собственности является бремя содержания имущества. В данном случае владелец 
социального блага несет расходы по сохранению объекта своей собственности и защиту его от других лиц (ниже будут даны подробные пояснения). Бремя содержания также включает риск потери социального блага в случае неэффективного его использования и этот риск возникает с момента перехода данного блага к собственнику.

Соответственно, как в любых других сферах, отношения собственности в социальной сфере включают отношения самого собственника к социальному благу как к объекту собственности и отношения между собственником и несобственником. Первое отношение проявляется прежде всего в процессе пользования. Но с другой стороны, это пользование не должно нарушать прав и законных интересов других экономических агентов или приносить им вред. Однако это условие применимо лишь в отношении пользования социальным благом, вытекающего из правовых актов и юридических сделок, т.е. законного пользования. Например, нельзя говорить о правомерности, если госслужащий, благодаря наличию властных полномочий, получает ренту методом коррупции. И наоборот, пользование лицензией на какой-то вид деятельности осуществляется на законных основаниях. Более того, соблюдать все условия лицензии и закона, в противном случае он будет лишен своего блага в принудительном порядке.

На психологическом уровне также проявляются отношения между «владельцем» и социальным благом. На уровне мышления владелец осознает принадлежность ему определенного блага, и он может этим правом воспользоваться ради достижения своих целей или извлечения пользы для себя лично.

Что касается отношений между «владельцем» блага и третьими лицами, то они проявляются в процессе распоряжения этим благом как «абстрактным имуществом», осуществляемого путем трансакции. Если пользование социальным благом не защищается законом, то применяются специфические формы защиты. Например, юридически госчиновник наделен властным полномочием и лишить его этого полномочия можно только путем отстранения от должности. Поэтому способами защиты властного полномочия могут быть тесные личные, даже дружеские контакты с руководством и т.п. Причем «владелец» властного полномочия несет трансакционные издержки в виде проведения семейных встреч, совместного отдыха и т.п., ко- торые впоследствии компенсируются гарантией «безопасности владения» социальным благом. Кроме того, руководство может гарантировать и защиту от посягательств третьих лиц, при условии, если последние не предложат руководству большие выгоды, получив тем самым большее покровительство. Такой механизм формирует так называемые «административный» и «политический» рынки, на которых предметом торговля являются властные полномочия.

В качестве специфического способа защиты властного полномочия социальным благом может применяться временной отказ от непосредственного пользования этим благом в личных целях «до лучших времен». За период тактики соблюдения закона за собственником властного полномочия сохраняются его права до того момента, когда из блага можно будет получить незаконный доход. Может случиться и более сложный способ защиты владения социальным благом, когда лицо, формально владея властным полномочием, фактически временно или на постоянной основе передаёт его другому лицу, например, ниже стоящему по должности чиновнику, которое по договоренности будет незаконно им пользоваться, отчисляя первому часть получаемой ренты. Таким образом, официальный владелец формально закона не нарушает, а в случае выявления нарушений можно их списать на субъекта, которому фактически были переданы полномочия и получить только дисциплинарное взыскание за ненадлежащий контроль за подчиненными, сохранив за собой место и должность. В тоже время такой владелец получает доход от незаконного косвенного пользования своим благом. Здесь речь идет о возникновении производных отношений собственности по поводу социального блага. Такие отношения выгодны и производному «собственнику», которому передается социальное благо и он, хоть и рискует, но в тоже время получает выгоду от пользования социальным благом.

Если пользование социальным благом правомерно и вытекает из закона и юридической сделки, то его владелец получает юридическую защиту прав и законных интересов от незаконного вмешательства третьих лиц (например, если арендодатель или третьи лица пытаются незаконно препятствовать осуществлению аренды помещения путем отключения тепло-, водо- или электроснабжение).

В связи с тем, что социальные блага могут 
быто предметом отчуждения-присвоения, то можно выдвинуть гипотезу о существовании первичных и производных отношений собственности в социальной сфере. Первичные отношения собственности возникают, когда социальное благо ещё не находилось в чьей-либо собственности» (например, если чиновник получил управленческие полномочия по принятию какого-либо решения непосредственно от государства, или руководитель вновь созданной организации в силу своего назначения на должность) и он становится первичным собственником этого полномочия.

Когда же первичный носитель социального блага передает право пользования другому лицу (официально или неофициально), а в определенных пределах и распоряжаться, то возникают производные отношения собственности трансакционного типа. Заметим, что при возникновении производных отношений собственности в трансакционной сфере право пользования социальным благом как бы раздваивается:

- субъект, получающий социальное благо во «владение», осуществляет непосредственное пользование;

- он же осуществляет косвенное пользование и получает доход (выгоду) от блага и после его передачи производному собственнику в виде части передаваемой ему ренты от пользователя благом или в виде арендной платы субарендатора при передаче ему права аренды и т.д.[2]

Завершая исследование специфики отношений собственности в социальной сфере необходимо сделать вывод.

На современном этапе содержание категории «институт собственности» расширяется и выходит за рамки экономической теории. В настоящее время исследованы только отношения собственности в материальной и духовной сферах и отсутствует представление о существовании правомочий в отношениях собственности в социальной сфере. Исходя из плюралистического методологического подхода к пониманию института собственности, мы пришли к выводу, что в социальной сфере возникают специфические отношения собственности между экономическими агентами по поводу отчуждения-присвоения социальных благ, непосредственно связанных с продуктами социального труда как проявление биосоциальной сущности человека. Соответственно, экономическое содержание этих отношений собственности составляют трансакционные издержки.

\section{Библиографический список}

1. Гражданский кодекс Российской Федерации (ГК РФ) № 51-ФЗ от 30.11.1994

2. Кузнецов А.А. Отношения собственности и эффективность трансакций: дис... канд. экон. наук: Владимир, 2002

3. Максимова Т.П. Методологические аспекты взаимосвязи экономической ментальности, ценностей и неформальных институтов в аграрной сфере экономики: сб. науч. тр. /Ценности и интересы современного общества. Москва. 2015.

4. Рязанова О.Е. Трансформация института собственности в условиях глобализации экономики: дис... докт. экон. наук. Москва. 2009. 


\title{
МЕТОДОЛОГИЧЕСКОЕ ЗНАЧЕНИЕ МАРКСИСТСКОЙ КОНЦЕПИИ ФИКТИВНОГО КАПИТАЛА ДЛЯ АНАЛИЗА СОВРЕМЕННОЙ СТАДИИ РАЗВИТИЯ ГЛОБАЛЬНОГО КАПИТАЛА
}

\author{
(c) 2018 Ермолаев Константин Николаевич
}

доктор экономических наук, профессор

заведующий кафедрой «Институциональной экономики и экономической истории»

Самарский государственный экономический университет

443090, г. Самара, ул. Советской Армии, д. 141

E-mail: ermolaevkn@yandex.ru

В данной статье рассматривается методологическое значение авторской трактовки категории «титульный капитал» для анализа сущности фиктивного капитала и его виртуализации, что является чрезвычайно важным в исследовании новых явлений и тенденций развития финансового рынка постиндустриальной экономики в эпоху глобализации.

Ключевые слова: титульный капитал, капитал-собственность, ожидаемая ценность фиктивный капитал, фиктивная стоимость.

Экономическое наследие К. Маркса в настоящее время все чаще становится объектом изучения представителями различных направлений экономической теории. Отмечаемое в 2018 году 200-лектие со дня его рождения, стало еще одним поводом обратиться к оценке ряда фундаментальных положений марксизма с позиции современности. Одним из них является теория фиктивного капитала, которая до настоящего времени остается весьма дискуссионной, хотя изучение её имеет длительную историю.

Исследуя природу капитала, воплощенного в ценных бумагах, К. Маркс [1] а затем и Р. Гильфердинг [2] использовали категорию «фиктивный капитал». Этот капитал рассматривался буквально как вымышленный (от латинского fictio - вымысел), не имеющий вещественного содержания и собственной стоимости, как специфическая разновидность капитала, не соответствующая канонам трудовой теории стоимости, существенно отличающаяся от реально функционирующего действительного капитала, разрывающая естественную непосредственную связь собственности с производством. Эти представления закрепились в качестве основополагающих в трудах их последователей в советской и современной российской экономической литературе.

Позднее, в 60-80 гг. XX в. в работах советских и российских экономистов [3] были существенно расширены представления о причинах возникновения, существенных признаках, типологии, развитии и субстанциональной основе такого капитала, а также его отличиях от реально функционирующего действительного капитала. Однако принципиальные подходы к пониманию его природы не изменились. Всеми авторами он трактовался как фиктивный, антипод реально функционирующего действительного капитала, не играющий никакой положительной роли в процессе воспроизводства.

Результаты этих исследований наряду с серьезными достижениями продемонстрировали известную ограниченность, связанную как с преувеличением значимости и абсолютизацией трудовой теории стоимости в целом и применительно к объекту исследования, так и с господством изолированного подхода к рассмотрению самой данной категории вне связи с развитием капитала как системного явления. В единстве эти две предпосылки привели к тому, что и большинство современных авторов отождествляют капитал, воплощенный в ценных бумагах и производных финансовых инструментах с фиктивным капиталом, трактуют его как своеобразную экономическую аномалию, как капитал, лишенный вещественного содержания, не имеющий собственной стоимости. (Схематично господствующая точка зрения по проблеме представлена на рисунке 1 ).

В наши дни проблема вновь актуализирована благодаря выходу третьего, исправленного, существенно дополненного и качественно измененного издания монографии А.В. Бузгалина 


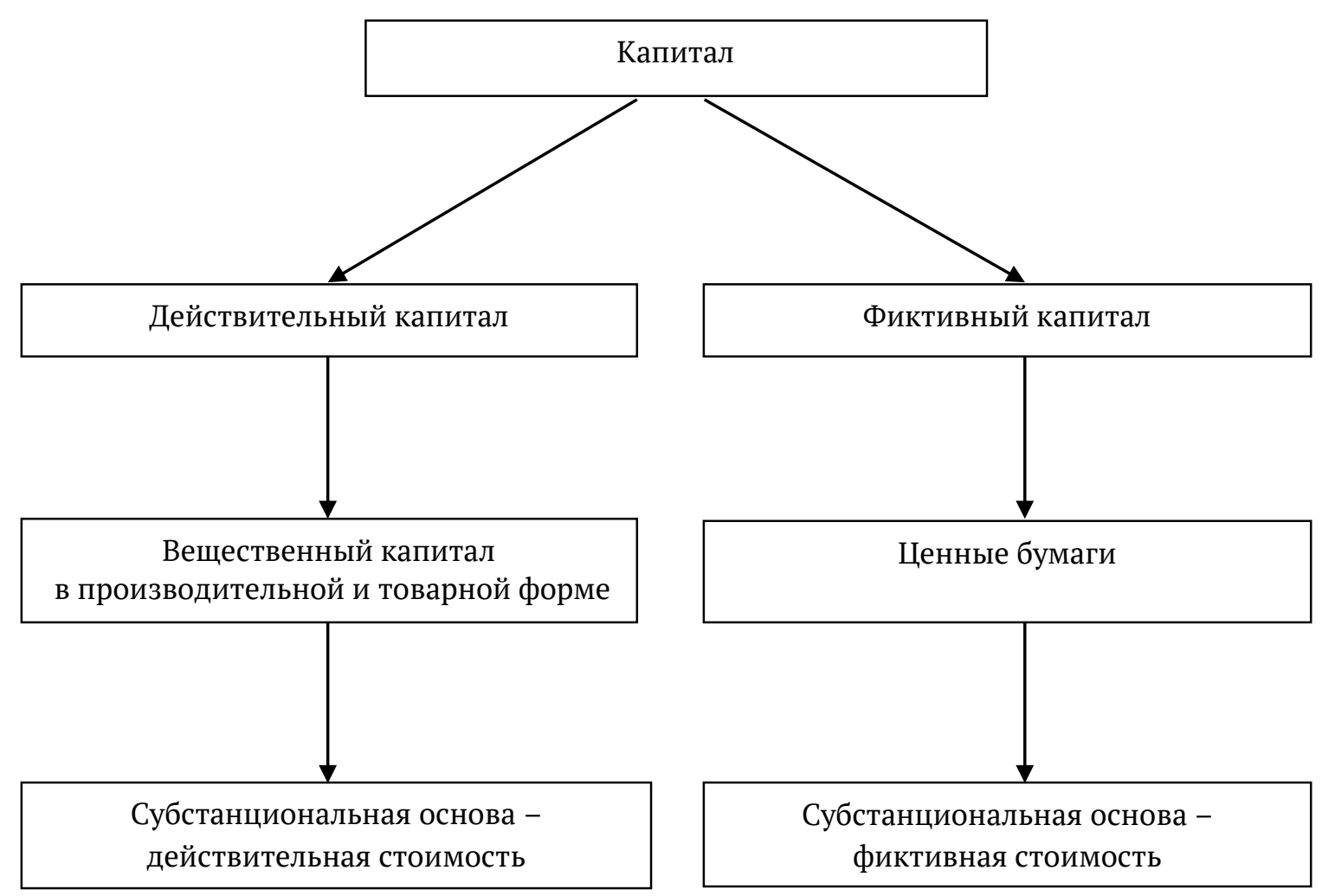

Puc. 1 Сложившиеся научные представления относительно природы фиктивного капитала

и А.И. Колганова «Глобальный капитал» [4], которое является значительным событием в развитии современной экономической теории. Будучи интегральным результатом многолетних исследований авторов, пролегомен «Капитала» XXI века, преследующий цель реактуализации методологии К.Маркса с позиции постсоветской школы критического марксизма на основе диалектики «снятия-развития», посвящен исследованию системных трансформаций производственных отношений капитализма. Актуальность проблемы обусловлена также процессом цифровизации экономики, заставляющим уточнить представления о так называемой «виртуализации» капитала

Одно из центральных мест монографии занимают идеи авторов относительно фиктивности современного глобального капитала и его виртуализации, которые несмотря на логическую стройность и всестороннюю аргументацию, представляются нам далеко не бесспорными. Изложение иной точки зрения по данной проблеме представляется для нас весьма принципиальным потому, что рассмотрение « виртуального фиктивного финансового капитала» для авторов книги имеет концептуальное и фундаментальное значение, отражая едва ли не самый существенный результат современного этапа системной трансформации капиталистических отношений.

А.В.Бузгалин и А.И. Колганов рассматривают фиктивный капитал и как результат трансформации денег из товара-эквивалента в виртуальные деньги, и как глобальный конкретно-всеобщий феномен, выступающий стихийным регулятором движения таких денег, всеобщим регулятором «сетевого» рынка, универсальным «оценщиком» финансовых активов, универсальным механизмом трансакций. Кроме того, авторы характеризуют его как превратную (видимостную) форму, отражающую мнимое содержание, принципиально отличное от действительного, функционирующую в превратном (общественно бесполезном, не создающем материальные и культурные блага) секторе позднего капитализма (сфере многократно мультиплицированных превратных форм), благодаря которым прибыль генерируется в сфере обращения, а также реализуется гегемония глобального корпоративного капитала. Эту сферу авторы оценивают как паразитическую, раковую опухоль на теле стареющего капитализма.

Авторы монографии полагают, что это видимостное, превратное «перевернутое» содер- 
жание данного явления неслучайно и адекватно отражает внешние, видимостные, маскирующие сущность механизмы функционирования рынка. Эти механизмы отражают отрыв движения денежного капитала от движения действительного (производительного) капитала, выражающийся в угнетении «правомерных», «естественных» функций денежного капитала (т.е. тех, что обусловлены его генезисом как средства обслуживания движения производительного капитала, его бытием-для-иного) и росте его «самодавлеющих» функций (для-себя-бытия), основанных на использовании спекулятивных эффектов.

Генезис виртуального фиктивного финансового капитала, по мнению авторов, отражает самоподрыв системообразующих производственных отношений капитализма на базе их прогресса, подрыв капиталистического производства, поскольку, будучи оторванным от материального производства по своей природе, такой капитал приобрел способность многократно увеличивать свои объемы и власть за счет неких виртуальных процессов в финансовой сфере, производства самого себя (денег) из самого себя (денег). Будучи продуктом развития глобализации, тотальных сетей и информационных технологий он стал частью виртуальной реальности, воплощенной в электронных носителях, способных выражать сколь угодно большие денежные суммы в сколь угодно малом носителе, перемещать их с практически мгновенной скорости, хранить сколь угодно долгое время без каких либо издержек, осуществлять трансакции в дватри триллиона долларов в день. Это электронная форма существования сопровождается неопределенностью, нестабильностью, вероятностным и неустойчивым бытием.

А.В.Бузгалин и А.И. Колганов рассматривают возникновение виртуального капитала и обслуживающих его виртуальных денег как новейший этап эволюции форм существования капитала превращение фиктивного капитала в виртуальный капитал, т.е. капитал, стоимостная оценка которого неопределенна, место нахождения которого из-за частоты и многоступенчатости сделок также неопределенно, и собственник которого, по той же причине расплывчат и неуловим.

Данные авторы характеризуют такой капитал как основу фиктивного (симулятивного) рынка, все атрибуты которого все более отрываются от своей основы (частного труда обосо- бленных производителей) и живут за счет самопродуцирования социально-экономической формы, где рыночные формы создаются другими рыночными формами и так далее, безотносительно к их стоимостной, трудовой основе.

В качестве результата А.В.Бузгалин и А.И. Колганов делают фундаментальный вывод [5], согласно которому виртуальная форма этого капитала оказывает, как было отмечено выше, значительное влияние на его содержание:

1. Капитал становится принципиально более мобилен во времени и пространстве, нежели капитал, имеющий другую форму, а скорость оборота капитала имеет принципиальное значение. Виртуальное бытие капитала качественно увеличивает эту скорость, позволяет ему перемещаться в любые точки пространства с практически мгновенной скоростью и с минимальными «транспортными» издержками. Тем самым виртуальный капитал обретает такой носитель, такое материальное воплощение, которые сами по себе являются всемирными и вечными: информация устаревает лишь морально.

2. Виртуальный капитал-деньги оказывается связан с конкретным субъектом, с конкретным положением в социальном пространстве-времени лишь по форме собственности и может менять своего хозяина сколь угодно быстро и часто. Тем самым виртуальный капитал - это капитал, не только оторвавшийся от производства, но и не находящийся сколько-нибудь устойчиво в частной собственности каких либо лиц. Он не является объектом сколько-нибудь устойчивого регулирования и контроля со стороны какого-либо лица.

3. Противоречие между свойствами информации и свойствами капитала, его отчуждение и присвоение становятся феноменами, зависимыми прежде всего от формальных и тоже «виртуальных» правил, регулирующих его движение. Всякие материально-производственные и личностные связи постепенно исчезают и заменяются процессами, протекающими в компьютерных сетях. Те капитал становится зависимым от качества институтов, обеспечивающих поддержание и развитие капиталистической формы информационной сети в целом.

Виртуальный характер фиктивного капитала, по мнению авторов, означает и существенные изменения в социально-экономическом содержании капитала. Этот носитель позволяет в принципе позволяет любому капиталу стать 
всемирным, вечным и предельно подвижным. Имеющий такой носитель капитал лишь формально связан с конкретным собственником, и эти связи постоянно меняются, что является его атрибутивной характеристикой; он зависим во всех своих звеньях от единой информационной системы человечества и является предельно могущественным и предельно уязвимым (от хакеров, владельцев компьютерно-коммуникационных сетей).

Мы полагаем, что рассматриваемая точка зрения не является бесспорной потому, что имманентными системными сущностными свойствами фиктивного капитала называются виртуальность, симулятивность, превратность, свидетельствующие о самоподрыве атрибутивных свойств капитала как такового. Истоки данной позиции заключатся в воспроизведении на качественно новом уровне рассмотренной выше (рисунок 1) позиции сторонников трудовой теории стоимости, что невольно приводит к представлениям о фиктивном капитале как о виртуальном капитале, олицетворяющей процесс «самоподрыва» и «самоотрицания» капиталом самого себя.

Мы полностью согласны с данными авторами в том, что современный глобальный капитал обладает рядом новых черт, по сравнению с эпохой раннего капитализма. Очевидной является финансовая доминанта, выражающаяся в глобальной гегемонии финансового капитала над остальной экономикой и опережающем росте финансового сектора по сравнению с реальным. Налицо определяющее влияние этого сектора на всю систему аллокации ресурсов, направление потоков инвестиций. Не вызывает сомнений, что приоритетное развитие финансового капитала вызвало волну дерегулирования, финансовые спекуляции стали своеобразным «регулятором», субститутом государственного воздействия на экономику. Современный капитал не имеет локализации в пространстве и во времени, постоянно «странствует» по глобальному финансовому рынку, легко уходит из-под любого национального и международного контроля и регулирования. Такой капитал потенциально неустойчив, генерирует финансовую нестабильность, непредсказуемо зависит от действия случайных факторов.

Однако из выше перечисленных процессов А.В.Бузгалин и А.И. Колганов делают выводы, с которыми сложно согласиться. Изменения в характере функционирования современного капитала, данные авторы объясняют его виртуализацией, перемещением в компьютерное киберпространство, сферу транзакций, утратой связи со своей материальной основой и материальным носителем. По их мнению, современный финансовый капитал живет в компьютерных сетях и поэтому он движется постоянно и с очень высокой скоростью, ему свойственны постоянная смена субъекта собственности и размытость, диффузия прав собственности, чрезвычайно высокая мобильность во времени и пространстве, высочайшая концентрация при минимальной интеграции с производственным сектором. Авторы уверены, что виртуальный капитал рубежа XX-XXI вв. становится системой «пузырей» виртуального финансового капитала, которые пусты по своей сущности, но при этом, поглощают огромные и наиболее высококачественные ресурсы. Генезис информационного общества, создает для этого сектора адекватную материальную базу и интенсифицирует его прогресс.

Автор статьи придерживается иной точки зрения. Постоянно возникающее противоречие между стремлением к ничем не ограниченному движению и материально-вещественной ограниченностью конкретных форм воплощения приводит на известном этапе к отмеченному К. Марксом специфическому диалектическому раздвоению капитала на капитал-собственность и капитал-функцию. Капитал-функция, или реально функционирующий, находящийся в товарной, производительной и денежной формах, функционирует в конкретной сфере экономики, реализуя свою репродуктивную и созидательную природу, непосредственно генерирует процесс самовозрастание стоимости. Капитал-собственность, представляющий собой обособленно обращающийся на финансовом рынке титул собственности на истинный капитал, существует в виде ценных бумаг, деривативов и структурных финансовых продуктов. Его предназначение - быть представителем истинного капитала на финансовом рынке и опосредовать перераспределение стоимости, собственности, риска и информации. Эта особая бестелесная невещественная титульная форма существования капитала, опосредующая движение товара-капитал на финансовом рынке.

Благодаря возникновению и самостоятельному движению особого, «титульного» компонента, капитал как таковой, сохраняя свои атри- 
бутивные свойства, переходит в принципиально новое состояние, демонстрируя целый ряд новых особенностей проявления своих сущностных свойств, о которых мы упомянули выше. Однако процесс виртуализации затрагивает не весь капитал как таковой, взятый в целом, а лишь его титульный компонент. При этом он остается неразрывно связанным с капиталом-функцией потоками фундаментальной экономической информации, узами пучков правомочий отражающих фиксацию и изменение принадлежности капитала конкретным субъектам, механизмами хеджирования рисков, процедурами первичного и вторичного рынка капитала. Виртуальным стало лишь титульное движение капитала на финансовом рынке, реальное функционирование капитала осталось материально-вещественным. Диалектически противоречивое единство и взаимосвязь капитала-собственности и капитала-функции не исчезли, а приобрели новую виртуальную форму фиксации. Реально функционирующий, капитал не дематериализуется и не виртуализируется даже в эпоху высоких технологий, компьютеризации и цифровизации. В сети обращаются лишь титулы капитала.

Уважаемые авторы не только абсолютизируют виртуализацию современного капитала, но и рассматривают ее не иначе как проявление самоподрыва и самоотрицания капитала как производственного отношения. Мы категорически против такого понимания процессов, происходящих с современным капиталом.

Возникновение титульного капитала в результате диалектического разъединения капитала-собственности и капитала-функции действительно предполагает отрицание титулом материально-вещественных свойств истинного капитала, его распредмечивание. Но это отрицание диалектическое, сопровождающееся с сохранением «в снятом виде» сущностного единства и внутренней взаимосвязи между титульным и истинным капиталом как двумя диалектически-противоречивыми сторонами единой сущности - капитала как такового. Это не подрыв капитала как явления - это воспроизведение в качественно новом виде коренной сущности капитала, раскрывающей новые его грани.

Таким образом, мы рассматриваем виртуализацию как особую стадию развития титульного компонента капитала, а виртуальный капитал - как одну из форм существования титульного капитала.
Таким образом, автор убежден, что известная виртуализация означает не исчезновение и самоподрыв капитала, как это пытаются представить уважаемые вышеупомянутые авторы, а переход его в новое качество, в котором при сохранении его материальной основы и физической сущности одновременно возникают условия для принципиально новых технологических возможностей движения титульного капитала. Одновременно необходимо подчеркнуть, что те новые свойства и особенности современного капитала, которые подробно исследованы А.В. Бузгалиным и А.И. Колгановым, имеют большую научную ценность, поскольку позволяют с одной стороны, точно охарактеризовать состояние современного глобального капитала, а с другой, более глубоко раскрыть природу титульного капитала и его адекватность проблемам и вызовам эпохи информационной финансовой постиндустриальной экономики на этапе глобализации.

Поэтому автор статьи полагает, что позиция оппонируемой точки зрения, вместе с лежащей в ее основе концепция фиктивного капитала, отраженная на рисунке 1 не является, тупиковой, непродуктивной или полностью ошибочной. Мы полагаем, что она имеет несомненную самостоятельную научную ценность. И вся проблема заключается в том, что она развивалась, по нашему глубокому убеждению, применительно не к тому объекту. Практически все положения данной концепции, по нашему мнению, успешно применимы не к капиталу, воплощенному в титулах собственности, а к другому экономическому явлению - монополизированному рентопродуцирующему ресурсу, генерирующему рентные доходы и являющемуся фиктивным капиталом диаметрально противоположным действительному капиталу реального сектора экономики, на что недвусмысленно указывали Ж. Сисмонди и В. Зомбарт. К глубокому сожалению рентные аспекты теории фиктивного капитала длительное время вообще не брались во внимание практически всеми авторами, и лишь в работах А.В. Мещерова [6], и выполненных под их руководством диссертациях, они стали исследоваться и развиваться с использованием категорий рента и ложная социальная стоимость. (Схематично позиция, защищаемая автором, представлена на рисунке 2).

Такое понимание природы фиктивного капитала и сущности процесса виртуализации, не умаляя методологической и теоретической 


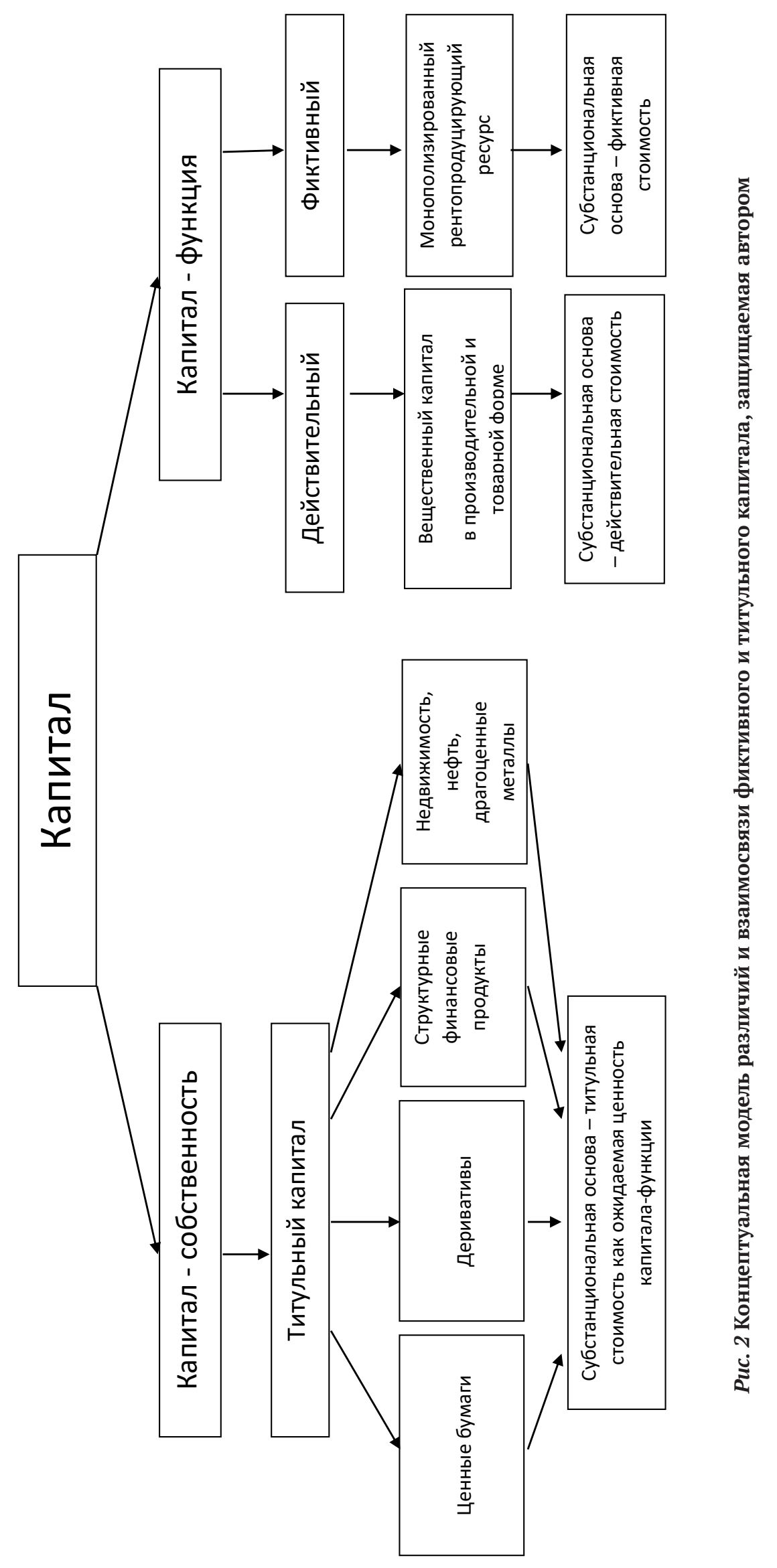


значимости концепции «виртуального фиктивного финансового капитала» А.В.Бузгалина и А.И. Колганова, требует внесения существенных уточнений в характеристику этого феномена нынешнего этапа системных трансформаций глобального капитала.

\section{Библиографический список}

1. Маркс К., Энгельс Ф. Соч.,2-е изд., Т. 25 Ч. 2 с. 18-80

2. Гильфердинг Р. Финансовый капитал. Исследование новейшей фазы в развитии капитализма.М.: Соцэкгиз, 1959. 490 с.

3. Аникин А.В. Кредитная система современного капитализма (исследование на материалах США).М. Наука,1964. С. 28; Брегель Э.Я. Денежное обращение и кредит капиталистических стран.М.: Финансы,1973. 355с.; Коган А.М. Методология исследования кредита в «Капитале» К. Маркса // Вестн. Моск. ун-та, Сер. 7., Экономика,1967.№ 4. С. 31; Краткий курс политической экономии: учеб. пособие. В 2 т. Т. 1/ под ред.Н.А. Цаголова.3-е изд., перераб. и доп. М.: Экономика,1973. 831с.; Леонов С. Фиктивный капитал: содержание и виды.//Экон. Науки. 1980.№ 9 С. 28-33; Мусатов В. Т. Некоторые вопросы анализа категории «фиктивный капитал»// Вестн. Моск. Ун-та,1976.№ 5.С.25-56; Розенберг Д.И. Комментарии к «Капиталу» К.маркса.М.: Экономика,1983. 720 с.; Трахтенберг И.А.денежное обращение и кредит при капитализме. М.: Изд-во АН СССР,1962.C.438-439

4. Бузгалин А.В., Колганов А.И. Глобальный капитал. В2-х т. Т. 2 Теория: Глобальная гегемония капитала и ее пределы («Капитал» re-loaded).-Изд.3-е, испр. и сущ. доп.-М.: ЛЕНАНД,2015-912 С.

5. Бузгалин А.В., Колганов А.И. Глобальный капитал. В2-х т. Т. 2 Теория: Глобальная гегемония капитала и ее пределы («Капитал» re-loaded).-Изд.3-е, испр. и сущ. доп.-М.: ЛЕНАНД,2015 -С 269.

6. Мещеров А.В. Действительная и фиктивная стоимость: ретроспективы и современность [Текст]// А.В. Мещеров .-Экономические науки.- № 1, 2016г, С. 7-13.; Мещеров А.В. Современная экономика и общий закон стоимости [Текст]// А.В. Мещеров .-Экономические науки.- № 2, 2016г, С. 7-14

Поступила в редакцию 04.08.2018 

ЭКОНОМИКА. ЭКОНОМИЧЕСКИЕ НАУКИ

\section{ЭКОНОМИКА И УПРАВЛЕНИЕ НАРОДНЫМ ХОЗЯЙСТВОМ}





\title{
ОТ МАТЕРИАЛЬНО-ТЕХНИЧЕСКОГО СНАБЖЕНИЯ К ЛОГИСТИКЕ И ОБРАТНО
}

\author{
(c) 2018 Плоткин Борис Кальманович \\ доктор экономических наук, профессор \\ Ассоциация содействия промышленности Научно - экономический комитет \\ г. Санкт-Петербург \\ E-mail:kafedra-kl@yandex.ru \\ (c) 2018 Сосунова Лильяна Алексеевна \\ доктор экономических наук, профессор \\ Самарский государственный экономический университет \\ 443090, г. Самара, ул. Советской Армии, 141 \\ E-mail: kafedra-kl@yandex.ru
}

В статье рассматриваются вопросы: становления логистики, ее взаимосвязь с материально техническим снабжением, представление и осведомленность о логистике; логистика как цепь поставок; транспортная сущность логистики; система кросс - докинг.

Ключевые слова: логистика, материально-техническое снабжение, рыночная экономика, отраслевая логистика, предметная логистика, транспортные услуги, кросс - докинг.

Российская экономика для своих рыночных преобразований получила логистику в полной теоретической готовности. Становление логистики шло в направлении распространения и адаптации её применительно к российским реалиям.

Теоретический потенциал логистики включал научные достижения, наработанные в предыдущий период - в период централизованной плановой системы материально-технического снабжения [1].

Логистика была введена в научный и практический оборот с началом перехода на рыночные товарно-денежные отношения между предприятиями. Появление логистики было обусловлено тем, что в административно-командной экономике был присущ постоянный дефицит материальных ресурсов для производственных нужд, вследствие чего предприятия испытывали трудности в снабжении. К моменту рыночных преобразований материально-техническое снабжение как вид деятельности и профессия были весьма скомпрометированы: потребовалось другой наименование и того и другого. Так появилась логистика.

Изначально логистика использовалась в военном деле: для ведения военных действий необходимы огромные материальные затраты, предвидеть различные случайности, учитывать множество факторов, выполнять сложные рас- четы - все это требует высокого искусства. Такое искусство именуется греческим словом «ло-

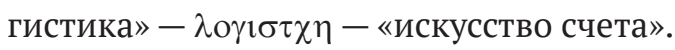

Авторитетные энциклопедические словари (Вебстер, Ларусс) слово «логистика» дают с пометой «воен.» и объясняют как «тыл и снабжение вооруженных сил». Так логистика была распространена на всё снабжение. Соответственно кафедры материально-технического снабжения стали именоваться как кафедры логистики.

Материально-техническое снабжение стало осуществляться с помощью оптовой торговли продукции производственного назначения, вследствие чего логистика, по праву, стала именоваться «коммерческой».

K началу экономических преобразований в полной мере сформировалась научно-теоретическая база материально-технического снабжения, которая в полной мере должна быть использована в логистике. К числу важнейших достижений предшествующего - планового периода следует отнести:

1) была сформирована достаточно развитая теория нормирования расхода материальных ресурсов;

2) разработаны методические основы достоверного определения потребности в материальных ресурсах с помощью метода «прямого счета»;

3) обоснован порядок расчета цен закупки 
и определения сумм материальных затрат;

4) сформирована совокупность критериев для оценки качества поставщиков, что является составной частью алгоритма оптимизации закупок;

5) разработаны методические основы расчета календарных графиков поставок материальных ресурсов на предприятие;

6) обоснована необходимость выполнения услуг при поставках продукции - подготовка материальных ресурсов к производственному потреблению (раскрой, нарезка, сортировка и т.п.);

7) отработана система количественной и качественной приемки поступающей на предприятие продукции;

8) получило признание научное управление запасами.

Следует подчеркнуть, что все достижения научной мысли в основном были только в теории, поскольку плановая система не давала предприятиям необходимой для этого самостоятельности и не стимулировала организацию материально-технического снабжения на оптимальном уровне.

В условиях рыночной экономики большинство научных достижений предшествующего периода с помощью логистики стали использоваться в снабжении производственных предприятий.

Накопленный научный потенциал вывел логистику в число новых экономических наук. Одновременно стало ясным, что полное и адекватное освоение логистики как науки требует от ученых и практиков высокого профессионализма и интеллекта. Иными словами, логистика может развиваться и использоваться на практике только под воздействием человеческого фактора - при наличии высококвалифицированного персонала [2].

Начало для логистики было весьма многообещающим. Те, кто кое-что слышал о логистике и не путал её с логикой, восприняли логистику с большими надеждами на будущее - это были специалисты «снабженческой» школы. Был энтузиазм - энтузиазм обусловлен тем, что благодаря рынку «сбылись мечты» снабженцев, а именно:

1) появилась в полном объеме оптовая торговля средствами производства;

2) был ликвидирован товарный дефицит, в том числе и на продукцию производственного назначения;

3) появилось самостоятельность предприятий - ушел в прошлое диктат «плана» и вышестоящих «руководящих» органов;

4) стало возможным применять методы теории управления запасами;

5) стало возможным оперативное маневрирование материальными ресурсами;

6) стали развиваться услуги и инфраструктура при поставках продукции;

7) существенно сократились документооборот и отчетность;

8) отменена монополия внешней торговли - расширилось рыночное пространство.

Интенсивно стали проводиться научные исследования по логистике. Выявились два направления научных исследований по логистике:

1) отраслевая логистика - например, логистика машиностроения, логистика сельского хозяйства, логистика угольной промышленности, логистика жилищно-коммунального хозяйства и т.П.;

2) предметная логистика - применительно к разным видам товаров и услуг, например, логистика строительных материалов, логистика мясной продукции, логистика фармацевтической продукции и т.п.

Но при этом нередки случаи, когда логистика просто «притягивалась за уши» к той или иной проблеме. Появились такие «логистики»: «логистика отдыха и досуга», «биржевая логистика», «банковская логистика», даже такая экзотическая логистика, как логистика девелопмента и таких примеров - множество.

Снабженческо-сбытовая деятельность получила весьма мощный импульс, но на практике меньше всего это связывалось с логистикой работники использовали накопленные квалификацию и опыт, но без должного интереса к логистике. Как уже отмечалось, исчезли трудности со снабжением, а сбыт скорее связывался с маркетингом и меньше всего с логистикой.

В отличие от логистики маркетинг широко освещался не только в специальной литературе, но в средствах массовой информации. До настоящего времени практические работники - менеджеры и специалисты - имеют лишь приближенное представление о логистике [3].

Для выявления осведомленности о логистике был проведен опрос среди работников производственных и торговых предприятий. Результаты указанного опроса представлены в табл. 1 . 
Таблица 1. Представление и осведомленность о логистике

\begin{tabular}{|c|l|c|}
\hline №№ пп & \multicolumn{1}{|c|}{ Представления о логистике } & \%\% \\
\hline 1 & Транспортные услуги и перемещение продукции & 38 \\
\hline 2 & Транспортная доступность и подъездные пути предприятия & 30 \\
\hline 3 & Формирование и поддержание запасов на необходимом уровне & 12 \\
\hline 4 & Закупки товаров для производственной и торговой деятельности & 8 \\
\hline 5 & Приемка товаров в торговой сети & 6 \\
\hline 6 & Сбыт, продажи, обслуживание покупателей & 4 \\
\hline 7 & Общее руководство фирмой & 2 \\
\hline & Итого & 100 \\
\hline
\end{tabular}

Важно отметить, что опрос проводился в профессиональной среде, а поэтому все ответы в той или иной мере касались логистики. Однако большинство логистику ассоциирует с транспортом (68\%). Примечательно, что к логистике некоторая часть торгово-промышленного персонала относит и запасы, тем самым признается место запасов в логистике.

Такие базисные логистические процессы как «закупки» и «продажи» весьма малая часть опрошенных (12\%) относит к логистике. Такое суждение было обусловлено тем, что среди участников опроса были работники розничных сетей и обслуживающих их распределительных центров.

Некоторые профессионалы-экономисты логистикой считали техническую эксплуатацию транспортных средств, работу с персоналом, проведение выставок и ярмарок для продвижения новых товаров, оценку эффективности работы менеджеров, консультационная деятельность и многое другое. Такое многообразие суждений, как уже отмечалось, обусловлено стремление «притянуть»к логистике всё без разбора. Но в то же время представляется отрадным, что экономисты в своем большинстве перестали смешивать «логистику» с «логикой» - уяснили, что это разные вещи.

Следует признать, что объемная научная информация по логистике носит в основном теоретический характер - на долю практики приходится не более $5 \%$.

Итак, во что трансформировалась логистика и её современное состояние? Из всего изложенного можно сделать следующие выводы:

1. Логистика меньше всего считается альтернативой и синонимом материально-технического снабжения, поскольку товарный дефицит ликвидирован и тем самым исчезли трудности в снабжении. Такое положение вызывает сомнение в необходимости логистики как самостоя- тельного вида деятельности с таким названием для снабженческо-сбытовой деятельности;

2. Почти полностью игнорируется финансовая составляющая материально-технического снабжения, ибо деятельность служб снабжения, как и прежде, направлена на обеспечение производства материальными ресурсами.

Не соблюдается требование, согласно которому материальными ресурсами должно обеспечиваться только конкурентоспособное производство. Как только предприятие становится неспособным получать доход необходимой величины, снабжение должно прекращаться. Нарушение указанного требования является одной из причин долгов предприятия, а то и банкротства.

3. Притом, что трудности возникли с реализацией готовой продукции, персонал службы сбыта процессы продаж не связывают с логистикой - в сбытовой деятельности приоритет отдается маркетингу. Однако на практике получаемая маркетинговая информация ещё не используется надлежащим образом в системе продаж. Бытует мнение, что трудности с продажами обусловлены внешними факторами: общей рыночной ситуацией, макроэкономическими действиями, конкуренцией, платежеспособностью и др. В ограниченном объеме для некоторых видов продукции применяются логистические приемы сбыта с использованием концепций Effective Customer Response (ECR): «Эффективная реакция на запросы потребителей» и Vendor Managed Inventory (VMI): «Управление запасами поставщиком».

4. Ключевое понятие логистики как цепи поставок в реальности представляют собой концзептуальную систему, а поэтому на микроэкономическом уровне, т.е. на практике являются абстракцией.

Предприятия, образующие «цепь поста- 
вок», функционируют независимо друг от друга, ориентируясь на свои собственные интересы, т.е. «цепь» в виде системы не образуется. Концепцию логистики SCM «Управление цепями поставок» следует признать неудачным заимствованием, поскольку таковых в реальности нет. Для западной экономики с её многолетним опытом применение SCM вполне обосновано, поскольку предприятия применяют логистические концепции в полном объеме. В российской экономике цепи поставок в той или иной мере функционируют в строительстве и военно-промышленном комплексе (ВПК) благодаря наличию на предприятиях этого комплекса представителей заказчика.

Следует отметить, что на практике происходит процесс кластеризации - образования кластеров в виде групп предприятия - производственных и торговых. В данном случае просматривается предметная специализация кластеров.

Предприятия каждого кластера функционируют в автономном режиме, руководствуясь своими интересами. Но при этом проявляются и объективно существуют неформальные связи: профессиональные, технологические, консультационные и др. В силу универсальности логистики (в данном случае её «всеядности») появляются рассуждения о «логистизации кластеров» или о «кластерной логистике». Так, в статье Борисенко А.Н. логистика рассматривается как «адекватная система логистики не ограничивается управлением отдельными запасами или транспортными потоками, а представляет собой концепцию исследования и повышения эффективности производственных систем, включающих несколько имущественно-хозяйственных комплексов» [4].

В современной экономике полностью отсутствует логистическая деятельность как реализация на практике научного потенциала, каким обладает теория логистики. Такое положение обусловлено тем, что логистика не получила должного распространения в практическом сообществе экономистов.

В действующей номенклатуре должностей отсутствуют должности с наименованием «логист» или «логистический» - такое же положение наблюдается и в штатных расписаниях производственных предприятий.

Логистика по-прежнему остается экзотикой. В данном аспекте представляет интерес срав- нение с маркетингом. Так, маркетинг как рынковедение или наука о рынке, весьма широко известен и в крупных оптово-торговых центрах имеются престижные должности - «маркетолог», но при этом отсутствуют службы маркетинга на производственных предприятиях.

Парадокс заключается в том, что логистика охватывает всю реальную экономику - все процессы товародвижения в натурально-вещественной и стоимостной формах, а маркетинг имеет дело только с информацией и результатом маркетинговой деятельности также является информация. Возникает вопрос: «Имеются ли в экономике профессионалы по логистике?» Да, имеются, но называются они по-другому и по-разному: от новых «менеджеров» и до традиционных работников по соответствующим направлениям - по закупкам, по продажам, по транспорту.

Современный инструментарий логистики полностью компьютеризирован: все логистические концепции от SCM и до VMI включают программные модули. Компьютерные технологии поглотили логистику. Сформировалась автоматизированная логистическая система управления на качественно новом уровне в русле всеобщей компьютеризации экономики.

В предыдущие периоды вычислительная техника была помощником работника - в настоящее время компьютеры являются партнерами специалистов, при этом функции специалистов - это осмысление результатной информации и принятие управленческих решений.

В целом логистика вернулась к своей доминанте - перемещению и транспортировке. В настоящее время логистика связывается именно с транспортом.

Принципиальное различие между логистикой и транспортной отраслью заключается в том, что логистическая транспортировка осуществляется в неразрывной связи с экономикой и перевозимыми товарами - с процессом товародвижения [5]. Транспортная отрасль в основном это техническая эксплуатация транспорта.

Среди собственно логистических форм организации транспортировки следует отметить унимодальные и мульти(интер)модальные перевозки, терминальные и комбинированные перевозки.

Кроме того, специальными правилами регламентируются условия перевозки и фрахта 
(ФАС, ФОБ, СИФ и др.), формы коносаментов и других перевозочных документов, условия оплаты и многое другое.

Таким образом, подготовка к организации и осуществления перевозок требует затрат высокопрофессионального труда персонала специализированных служб и организаций (фирм). На практике вся такая работа, будучи весьма сложной и ответственной, в той или иной мере связывается с логистикой. Более того, работники, занятые перевозочным процессом, полностью сознают, что их деятельность является логистической.

Частью собственно логистики, т.е. её транспортной сущности, является система кроссдокинг.

Кросс-докинг - Cross-docking в переводе с английского значит «прямая стыковка» - процесс приёмки и отгрузки товаров и грузов напрямую, без размещения в зоне долговременного хранения.

Кросс-докинг является совокупностью логистических операций, благодаря которым отгрузка со склада и доставка товаров максимально точно согласуются по времени. В результате продукция доставляется за минимальный срок, а долгосрочное хранение товара на складе полностью исключается.

Кросс-докинг как логистический процесс выдвигает особые требования в адрес складского провайдера в цепи поставки. Рассматриваемая система доставка продукции может расценена как своеобразная концепция JiT - «Точно в срок».

Примечательно, что многие операции и процессы, будучи по своей сущности логистическими, применяются в хозяйственной деятельности под самыми разными названиями. Система кросс-докинг под названием «прямой вариант» издавна применяется на водном транспорте. В морских и речных портах выполняются погрузочно-разгрузочные работы по прямому варианmу: перегрузка грузов осуществляется непосредственно из трюмов судна в железнодорожные вагоны (вариант «судно-вагон») или из вагонов прямо в трюмы судов (вариант «вагон-судно»).

Следует подчеркнуть, что и в административно-командной экономике весьма интенсивно проводилась работа по совершенствованию транспортных процессов в системе снабжения. Эта работа - с точки зрения современности - была в полной мере логистической, хотя в то время такой термин был совсем неизвестен, т.е. дело не в названии, а в сущности проводимых работ.

Так, в частности, к таким работам следует отнести мероприятия, направленные на сопряжение материально-технического снабжения и транспорта. В рамках таких работ была создана Центральная диспетчерская служба складских комплексов, с помощью которой осуществлялось всестороннее и оперативное обслуживание автотранспорта предприятий-потребителей с помощью централизованной доставка грузов.

В современных условиях следует признать, что выражение «транспортная логистика» является тавтологией, ибо раз сказано «логистика», то речь будет идти о транспортировке.

Произошла трансформация логистики в общеэкономическую прикладную научную и учебную дисциплину.

Накопленная обширная научная информация по логистике должна стать теоретическим фундаментом для подготовки современных специалистов по экономике всех его специальностей.

В настоящее время понятие «логистика» получило вполне отраслевое значение и обозначает преимущественно всё, что связано с транспортом и включает весь комплекс основных и инфраструктурных процессов транспортных систем. Снабжение и сбыт следует именовать своими точными названиями.

Важно знать, что материально-техническое снабжение и сбыт есть форма экономического процесса обращения средств производства, а транспорт - отрасль материального производства.

\section{Библиографический список}

1. Проценко О.Д. Логистика // Большая российская энциклопедия: в 30 т. / председатель науч.-ред. Совета Ю.С. Осипов; отв. ред. С.Л. Кравец. Т. 17. Москва. 2010. С. 734 ISBN978-5-85270-350-7 (т. 17) ISBN5-85270320-6

2. Плоткин Б.К. Введение в коммерцию и коммерческую логистику: Учеб. Пособие. Санкт-Петербург. 1996. $171 \mathrm{c.}$ 
3. Плоткин Б.К., Сосунова Л.А., Корнев В.М. Проблемы компетентности специалистов образовательных услуг// Экономические науки. 2018. № 1. С. 22.

4. Борисенко А.Н. Логистика как концептуальная основа исследования территориально распределенных производственных сетей // Экономические науки. 2006. № 12. С. 22

5. Сосунова Л. А. Логистические индикаторы в потоковых процессах // Экономические науки. 2017. № 2. С. 115.

Поступила в редакцию 25.09.2018 


\title{
ЧЕЛОВЕЧЕСКИЙ КАПИТАЛ В СИСТЕМЕ ФАКТОРОВ ОПЛАТЫ ТРУДА КВАЛИФИЦИРОВАННЫХ РАБОТНИКОВ
}

\author{
(c) 2018 Соболев Эдуард Неньевич \\ доктор экономических наук, ведущий научный сотрудник \\ Институт экономики Российской академии наук \\ 117218, г. Москва, Нахимовский пр., д. 32 \\ E-mail: edsobol@rambler.ru
}

В статье исследуется связь оплаты труда квалифицированных работников с их человеческим капиталом. Показано, что в России эта связь прослеживается слабо. Предлагается система мер по преодолению деформаций в оплате труда, базирующаяся на более полном учете профессионально-квалификационных и образовательных характеристик работников.

Ключевые слова: человеческий капитал, заработная плата, квалифицированный труд, отдача от образования, дифференциация оплаты труда.

Спецификой российской практики оплаты труда является слабый учет факторов, отражающих накопленный работниками человеческий капитал. Важнейшими из этих факторов - уровень профессионального образования и опыт работы по специальности, в ходе которой человеческий капитал обновляется и модернизируется. На практике при установлении размера вознаграждения за труд важность этих характеристик перекрывается неоправданно высокой ролью факторов, которые не зависят от работника, а отражают объективные параметры того или иного рабочего места. Это сфера экономической активности (процветающие или стагнирующие отрасли), территориальный фактор (крупный город, небольшой город, сельская местность, благополучный или дотационный регион), устойчивость экономического положения и финансовые результаты конкретного предприятия (фирмы), где занят тот или иной работник, уровень социальной ответственности и зарплатные стратегии менеджмента.

Положение усугубляется и тем, что вопросы оплаты квалифицированного труда на сегодняшний день практически выпали из сферы ответственности российского законодательства. В фокусе его внимания преимущественно размер минимальной зарплаты. Порой кажется, что помимо МРОТа и его соотношения с прожиточным минимумом (ПМ) никаких проблем в оплате труда нет. А с учетом того, что коллективно-договорное регулирование тоже ориентируется на минимальные уровни, у нас сложилась деформированная практика дифференциации.

Вопреки распространенному мнению, со-

гласно которому деформации в области оплаты квалифицированного труда имеют истоки в рыночных преобразованиях последнего десятилетия прошлого века, эти проблемы в значительной степени были заложены еще в предшествующий советский период, когда более полному учету квалификационных различий препятствовала общая линия на выравнивание трудовых доходов и недопущения бедности наименее квалифицированных слоев рабочей силы, получающих минимальную заработную плату. Это нашло отражение в сжатии тарифной сетки в позднесоветский период.

В результате уже к 70-м годам прошлого века был практически утрачен относительно высокий социальный статус и уровень материального благополучия широких слоев квалифицированных работников, занятых как в отраслях нематериального производства (образовании, здравоохранении), так и в промышленности, строительстве, на транспорте (инженерно-технические работники). Дело дошло до того, что ходе социологических опросов представители этих категорий сплошь и рядом сообщали завышенный размер собственной зарплаты, так как стыдились ее размеров.

Таким образом, на пороге рыночных преобразований в нашей стране хотя и отсутствовала весьма острая для многих регионов мира проблема высокой и растущей дифференциации трудовых доходов, но в то же время сложилось серьезное отставание в области оплаты квалифицированного труда от наиболее развитых экономик. На тот момент отрицательные экономические следствия этого отставания были в 
основном купированы «железным занавесом», который делал невозможными значительные масштабы оттока квалифицированного труда в страны, обеспечивающие адекватную квалификации работников отдачу на человеческий капитал [1]. Негативные социальные следствия со своей стороны смягчались бесплатным доступом к продукту отраслей нематериального производства и высоким уровнем социальной защищенности населения. Рыночные реформы, с одной стороны, открыли ворота неконтролируемой утечке умов, с другой,- резко ухудшили общие условия воспроизводства рабочей силы, что сильнее всего затронуло ее наиболее квалифицированные и образованные слои.

На рубеже тысячелетий существенная доля квалифицированных работников в самых разных сферах деятельности либо оказалась невостребованными на рынке труда, либо получали мизерное вознаграждение. По данным социологического опроса, проведенного в этот период Институтом экономики РАН, среди работников, получающих заработную плату в размере прожиточного минимума и ниже около 30\% имели высшее, а еще около 45\% среднее профессиональное образование [2].

В сферах нематериального производства, где сосредоточена значительная часть наиболее образованной рабочей силы, средняя заработная плата отставала от отраслей с низкой долей обладателей высшего образования. Особенно пострадали организации бюджетного сектора, где доля лиц с высшим и средним профессиональным образованием на начало 2000-х гг. колебалась в пределах 30-40\% в сравнении с 18-23\% в остальной экономике.

Противовесом этой тенденции выступило появление новых видов деятельности в растущих сегментах рыночной экономики. Развитие информационных технологий, финансовых и деловых услуг способствовали расширению спроса на соответствующие категории квалифицированной и хорошо оплачиваемой рабочей силы. Однако положение других обширных сегментов квалифицированных работников до сих пор продолжает оставаться весьма неблагоприятным.

Жесткая ограниченность бюджетных средств на оплату труда как следствие ущербной социальной политики неизбежно требовала и требует использования пресловутого советского опыта тарификации, когда повышение минимальной оплаты в условиях бюджетных ограничений зачастую приводило к «сжатию» тарифной сетки. Аналогичные процессы имеют место и в настоящее время с системой должностных окладов в науке и образовании. Тем самым внутри бюджетной сферы нарушаются материальные стимулы к труду более высокой квалификации, а далее - по цепочке - сдерживается оплата квалифицированных работников и в других секторах экономики. При этом «сжатие» распространяется не на всех работников бюджетной сферы. Другие принципы и ставки применяются для категорий государственных служащих, в результате чего средняя заработная плата в органах государственного управления почти в два раза выше, чем оплата работников в отраслях социальной инфраструктуры. Это также способствует усилению межфирменных различий в противовес квалификационным.

Что касается оценки тенденций в зарплатном неравенстве, то основной негатив кроется не в размерах дифференциации (в США такая же, если не большая дифференциация в заработках). Более важно, что в России эти разрывы зачастую слабо связаны с профессиональными характеристиками работников, с их человеческим капиталом.

В 1990-х и начале нулевых годов Институтом экономики РАН было проведено несколько раундов обследования социально-экономического положения работников по одному кругу предприятий, которое выявило две основные тенденции во внутрифирменной дифференциации оплаты труда. Первая - рост разрыва между оплатой труда руководителей предприятия (администрации) и основной массой работников. Одновременно существовала вторая устойчивая тенденция сближения заработков квалифицированных и менее квалифицированных работников [3].

С тех пор прошло немало времени, но положение - по большему счету - мало изменилось. Так, Обследование заработной платы по профессиям, проведенное Росстатом в октябре 2017 г. показало, что по величине оплаты труда вне конкуренции являются руководители, чьи заработки почти в два раза превышают средний уровень для всех обследованных работников. (Когда было первое обследование в 2005 г., превышение составляло 75\%, т.е. за 10 лет оно существенно возросло). Работники высшей квалификации получают всего лишь на 12\% выше 
средней оплаты. Что касается остальных групп работников, то все они, начиная от «специалистов средней квалификации» до «неквалифицированных работников» по зарплате недотягивали до средней [4].

В целом, исходя из результатов последнего обследования, можно сделать следующие выводы. По-прежнему сохраняется сильная статусная поляризация между руководителями и остальными категориями работников по оплате. В то же время отметим, что аналогичная ситуация имеет место и в других странах. В докладе MOT, специально посвященном проблеме неравенства в оплате труда, отмечалось, что в развитых странах около 80\% работников получают зарплату ниже средней по организации [5]. Для основной массы российских работников связь фактора квалификации и оплаты труда просматривается, но не является линейной. К примеру, труд синих воротничков ценится, по крайней мере, не ниже, чем белых, хотя квалификация у вторых выше. С чем это связано: со стиранием различий в сложности труда белых и синих воротничков, отсутствием средств на дифференциацию (например, компрессия заработков может быть следствием повышения MPOT в условиях жестких бюджетных ограничений) или наличием дисбалансов в спросе и предложении на рынке труда, вопрос требует специального изучения.

В России имеем также относительно слабую зависимость заработков от возраста и стажа, что также свидетельствует о деформациях в отечественном механизме формирования оплаты труда. Более опытные работники старших возрастов, обладающие несравненно более высокой квалификацией, получают всего лишь на 30-40\% больше, чем молодые и неопытные работники. Для сравнения: в США разница составляет 2,5 раза. Типичной является такая ситуация, когда заработная плата вновь пришедшего работника быстро растет в первое десятилетие его трудовой деятельности, а затем рост замедляется и она остается практически неизменной в течение последующих 20-25 лет. Кривые заработков по трудовому стажу ведут себя аналогично кривым по возрасту [6].

Определенные потери стал нести фактор образования - важнейшая составляющая квалификации работника. Если со второй половины 1990-х гг. наблюдался интенсивный рост отдачи от образования, которая достигла 8\% на каждый дополнительный год обучения в начале 2000-х гг., то в дальнейшем началось снижение отдачи. К концу нулевых годов она стала составлять около 7\% [7]. По прогнозам некоторых экспертов отдача от образования в России продолжит снижаться, несмотря на противоположную мировую тенденцию [8].

Причин здесь несколько. Прежде всего, конечно, сырьевая ориентация экономики, слабое развитие высокотехнологичных отраслей, что объективно ограничивает спрос на услуги высококвалифицированных работников. Снижение отдачи во многом результат и расцвета так называемого псевдообразования, когда многие вузы превратились из места получения знаний в предприятие по выдаче корочек. Отметим и рост доли образованных работников, занимающих рабочие места, не требующие столь высокого уровня квалификации, а также работа не по специальности. В результате дифференциация в заработках по уровням образования сглаживается и наблюдаемая отдача от человеческого капитала оказывается ниже, чем она могла бы быть, если бы работники распределялись по рабочим местам в соответствии с имеющейся у них профессиональной подготовкой. Есть оценки, что премия за более высокое образование была бы в таком случае как минимум в полтора раза выше [9].

Нельзя сказать, что в политике оплаты труда ничего не делается. В результате опережающего роста зарплаты укрепились позиции квалифицированных работников, занятых в ключевых отраслях нематериального производства - в образовании, здравоохранении, культуре. Это привело к позитивным изменениям соотношения заработной платы по видам экономической деятельности [10]. В то же время заработки специалистов социальных отраслей по-прежнему отстают от заработков специалистов в других отраслях экономики. К тому же наблюдается необоснованный рост интенсивности труда

В стране сложилась деформированная практика дифференциации, когда зарплата одновременно страдает как от «переизбытка» дифференциации, так и от ее недостатка. С одной стороны, имеет место один из самых высоких по мировым меркам отрывов зарплаты топ-менеджеров крупных компаний от рядовых работников, а с другой, невысокая дифференциация для подавляющей части работников. Поэтому актуальней ставить вопрос не столько о снижении дифференциации до некоего «социально-нор- 
мального» уровня, сколько о более полном учете в зарплате профессионально-квалификационных различий, человеческого капитала [11].

Что конкретно следует сделать по преодолению деформаций в оплате квалифицированного и высококвалифицированного труда?

Среди практических мер, которые лежат на поверхности, можно выделить следующие:

1. Создать минимумы оплаты по основным квалификационным группам и систему их практического внедрения. В последнее время возникла тенденция сведения всех проблем к МРОТ. Однако, не менее, если не более важна проблема оценки труда в зависимости от квалификации и сложности. В любом случае должен быть сохранен определенный порог чувствительности при переходе от разряда к разряду, от менее сложного к более сложному труду. Иными словами, в гарантиях минимума оплаты нуждается не только простой, но и сложный труд.

2. Восстановить значение нормирования труда, что позволит соединить высокие нормативные требования к трудовому вкладу и достойную заработную плату. Это столь непопулярная в наш век популизма тема связи оплаты труда с производительностью. Кроме того нормирование должно поставить жесткий предел росту интенсивности труда, чтобы это не отразилось на качестве работы. Это весьма актуально не только в традиционных сферах, которые обычно отождествляются с нормированием, но и в таких отраслях как образование и здравоохранение, где указы президента инициировали интенсификацию труда [12]. Ясно, здесь нужны серьезные исследования по проблеме редукции труда, поскольку мы еще не имеем полной формулы, на основе которой могли бы переводить сложный труд в простой. К сожалению, сегодня этим никто не занимается. Знаменитый НИИ труда разрушен и поменял свою тематику, из-за нехватки средств закрылся журнал «Человек и труд», практически не готовятся специалисты по нормированию в высшей школе. Не утратил своего значения прямой учет фактора образования и опыта при определении ставок оплаты труда в государственном секторе. Здесь главное - найти базу, от которой надо отталкиваться. Ориентирами могут служить соотношения, имеющиеся на рынке рабочей силы в странах с развитой экономикой или наиболее продвинутых развивающихся стран.

3. Повысить долю тарифа (оклада) в заработке. Как известно, фактор квалификации и образования более всего влияет именно на основную часть заработка. В России доля тарифа весьма незначительна (около 50\%), а в США свыше 95\%. Многочисленные доплаты ориентируют работника не на результат, а на мнение начальства.

4. Развивать институты нерыночного регулирования зарплаты, прежде всего механизмы социального партнерства, которые более-менее успешно функционирует во многих европейских странах. В России они формальны и неэффективны, но без них регулировать зарплату в коммерческом секторе невозможно[13].

5. Усилить роль региональных тарифных соглашений. Для зарплаты важно, чтобы возросла обязательность соблюдения соглашений на всех уровнях. Это реально и более всего возможно на уровне регионального тарифного соглашения. Межпрофессиональные и квалификационные соотношения в рамках этих соглашений можно сделать обязательными для всех предприятий (организаций) региона вне зависимости от того, заключили ли они такое соглашение или нет. Подобный опыт имеется в европейских странах, в частности во Франции.

6. Реформировать профсоюзы. Следует повсеместно переходить к организации профсоюзов не по производственно-отраслевому, а профессиональному принципу. Это позволит сформулировать единую позицию работников в рамках профессиональной группы на переговорах с работодателями по вопросам оплаты труда.

7. Необходима информационная прозрачность зарплат по профессиям на рынке труда. При определении зарплаты расчет должен делаться не на интуицию и слухи, а на сведения о заработках по конкретным профессиям в регулярно издаваемых бюллетенях.

Реализация этих мер, по сути, будет означать движение к более справедливой оценке квалифицированного труда и к более социально оправданной дифференциации в российской экономике.

\section{Библиографический список}

1. Марцинкевич В.И. Инвестиции в человека: экономическая наука и российская экономика // Мировая экономика и международные отношения. 2005. № 9. С. 29-39. 
2. Соболев Э.Н., Ломоносова С.В. Оплата труда в российской экономике: динамика, факторы, направления преобразований. Научный доклад. Москва. 2003.

3. Воейков М.И., Анисимова Г.В., Соболев Э.Н. Природа, факторы и социальные аспекты внутрикорпоративного неравенства в России // Вестник Российского гуманитарного научного фонда. 2012. № 3 (68). С. $43-51$.

4. Сведения о заработной плате работников организаций по категориям персонала и профессиональным группам работников за октябрь 2017 г. (статистический бюллетень). Москва. 2018. http://www.gks.ru/wps/ wcm/connect/rosstat_main/rosstat/ru/statistics/wages/labour costs/

5. Global Wage Report 2016/17: Wage inequality in the workplace - Geneva: ILO, 2016. P. XIX.

6. Заработная плата в России: эволюция и дифференциация / Под ред. В. Гимпельсона, Р. Капелюшникова. Москва. 2007. С. 414-422

7. Лукьянова А.Л. Отдача от образования: что показывает мета-анализ // Экономический журнал ВШЭ. 2010. № 3. C. 328-348.

8. Soboleva I. Paradoxes of the measurement of human capital // Problems of Economic Transition. 2010. V. 52 . № 11. P. 43-70

9. Капелюшников Р.И., Лукьянова А.Л. Трансформация человеческого капитала в российском обществе. Москва. 2010. С. 66-67.

10. Соболев Э.Н., Соболева И.В. Тенденции и факторы дифференциации заработной платы в российской экономике // Вестник Российского экономического университета им. Г.В. Плеханова. 2014. № 5 (71). С. 33-50.

11. Соболев Э.Н. Социальная политика в сфере труда: критерии эффективности и направления модернизации // Вестник Института экономики РАН. 2017. № 2. С. 32-46.

12. Ржаницына Л. С. Без стимулирования труда не поднять его производительность / Вестник Института экономики РАН. 2016. № 5. С. 56-69.

13. Российская социально-экономическая система: реалии и векторы развития / Отв. ред. Гринберг Р.С., Савченко П.В. Сер. Научная мысль (2-е изд. перераб. и доп.). Москва. 2016. С. 417-425.

Поступила в редакцию 10.10.2018 

ЭКОНОМИКА. ЭКОНОМИЧЕСКИЕ НАУКИ

\section{ФИНАНСЫ, ДЕНЕЖНОЕ ОБРАЩЕНИЕ И КРЕДИТ}





\title{
ФОРМИРОВАНИЕ ДИНАМИЧЕСКИХ ИМИТАЦИОННЫХ МОДЕЛЕЙ ФИНАНСОВЫХ МЕХАНИЗМОВ КОНКУРЕНТНОГО ВЗАИМОДЕЙСТВИЯ МЕЖДУ БАНКАМИ НА КРЕДИТНОМ РЫНКЕ
}

\author{
(C) 2018 Сорокина Марина Геннадьевна
}

доктор экономических наук, профессор, заведующая кафедрой финансов и кредита Самарский национальный исследовательский университет имени академика С.П. Королева 443086, г. Самара, ул. Московское шоссе, д. 34

E-mail: ipoteka_sorokina@list.ru

В статье разработаны дискретные динамические имитационные модели финансового механизма конкурентного взаимодействия между банками, позволяющие определить траектории изменения финансовых параметров и на этой основе обосновать устойчивость равновесных состояний выбранных стратегий на кредитном рынке.

Ключевые слова: имитационная модель, механизм конкурентного взаимодействия, процентный доход, равновесное состояние.

Рассмотрим модель задачи выбора объемов кредитования на финансовом рынке, в котором учувствуют два коммерческих банка и решение этой задачи с использованием динамической имитационной модели. Для решения поставленной задачи сформируем вначале статическую модель по выбору объемов кредитования при заданной функции спроса на кредитном рынке, характеризующей конкурентный характер взаимодействия между участниками рынка. Статическую модель задачи выбора объема кредитования каждым участником представим в следующем виде:

$$
\begin{gathered}
\text { Пд }(y)=\left[\alpha_{0}-b L(y)\right] y_{i} \rightarrow \max _{y_{i} \in Y_{i}}, i=1,2, \\
L(y)=y_{1}+y_{2}, \alpha(L)=\varphi(L)=\alpha_{0}-b L(y), y=\left(y_{1}, y_{2}\right), \\
Y_{i}=\left\{y_{i} / 0 \leq y_{i} \leq L_{i}\right\}, y_{i} \geq 0, i=1,2
\end{gathered}
$$

где ПД $і$ (y) - величина процентного дохода, получаемая $i$-м банком от реализации кредита в объеме $y_{i} ; \alpha(L)=\varphi(L)$ - обратная функция спроса на кредиты одного сегмента; $L_{i}-$ спрос на кредиты со стороны заемщиков, выдаваемых $i$-м банком; $L(y)$ - суммарный объем выдаваемых кредитов участниками кредитного рынка; $Y_{i}$ - допустимое множество объемов кредитов, выдаваемых $i$-м банком; $y=\left(y_{1}, y_{2}\right)-$ вектор объемов выдаваемых кредитов участниками рынка; $b$ - скорость убывания обратной функции спроса; $\alpha_{0}-$ начальная процентная ставка однотипного кредита.

Модель принятия решений каждым банком по выбору кредита (1) рассмотрена в более общем виде в работах $[1,2]$.

Предположим, что оптимальное решение модели (1) находится внутри допустимой области, тогда, как показано в работах [2], выбор оптимального объема кредитования каждым банком с учетом стратегии конкурента определяется в соответствии со следующими уравнениями:

$$
\left\{\begin{array}{l}
Y_{1}^{0}=\frac{\alpha_{0}}{2 b}-\frac{1}{2} Y_{2}^{0} \\
Y_{2}^{0}=\frac{\alpha_{0}}{2 b}-\frac{1}{2} Y_{1}^{0} .
\end{array}\right.
$$

Как следует из полученной взаимосвязанной системы уравнений, объем кредитования выбираемых каждым банком зависит от параметров обратной функции спроса $L(y)$, количества участников кредитного рынка и начальной процентной ставки кредита $\alpha_{0}$, т.е. от параметров модели финансового механизма рыночного взаимодействия, описываемого системой уравнений (2). Рыночное взаимодействие между участниками рынка осуществляется во времени и, для исследования динамики конкурентного взаимодействия, представим систему уравнений (2) в дискретном динамическом виде:

$$
\left\{\begin{array}{l}
Y_{1}(t+1)=\frac{\alpha_{0}}{2 b}-\frac{1}{2} Y_{2}(t), \\
Y_{2}(t+1)=\frac{\alpha_{0}}{2 b}-\frac{1}{2} Y_{1}(t) .
\end{array}\right.
$$

Решение системы уравнений (3) осуществим 
с помощью имитационной динамической модели, изображенной на рис. 1. с использованием программного пакета MatLab и следующих исходных данных:

$\alpha_{0}=18 \%$ годовых; $b=1 * 10^{-6}$ проц./д.ед.;

$Y_{1}(0)=5^{*} 10^{4}$ д.ед.; $Y_{1}(0)=8 * 10^{4}$ д.ед.

Динамическая имитационная модель сформирована из следующих блоков: блоки входных исходных данных Constant; блока усилителя Gain; блок делителя Divide; блок сумматора Add; блок дискретного интегратора Unit Delay; блок осциллографа Scope; блок цифрового дисплея Display [3].

На рис. 2. представлены траектории изменения объемов кредитования выдаваемых банками в процессе взаимодействия с конкурентом.
Сплошной линией обозначены траектория объема кредитования первого банка, а пунктирной - объем кредитования второго. Как следует из полученных траекторий объем кредитования первого банка из начального объема $Y_{1}(0)=$ $5 * 10^{4}$ д.ед. увеличивается с каждой итерацией и достигает равновесного значения $Y_{1}{ }^{P}(t)=6^{*} 10^{4}$ д.ед. Объем кредитования второго банка из начального объема $Y_{2}(0)=8 * 10^{4}$ д.ед. уменьшается на каждой итерации и достигает равновесного значения $Y_{2}^{P}(t)=6 * 10^{4}$ д.ед. Равенство равновесных значения для первого и второго банка объясняется тем, что ни один из банков не имеет конкурентного преимущества относительно другого банка и поэтому суммарный объем рынка кредитования в $120 * 10^{4}$ д.ед. делится между

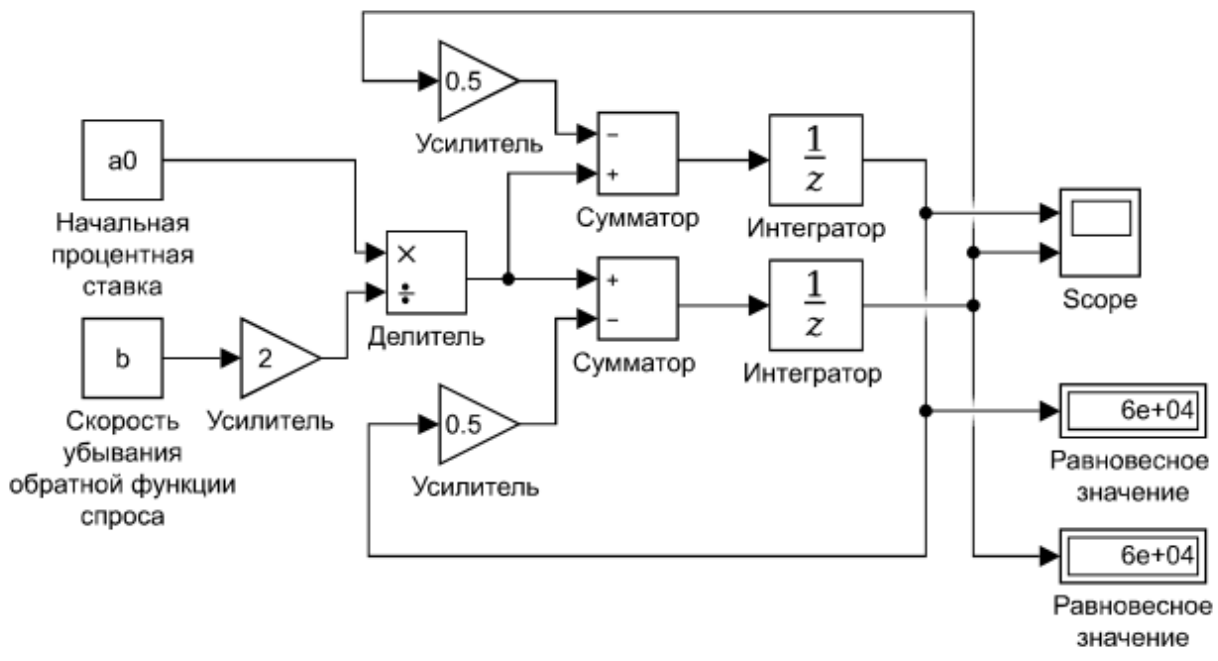

Puc. 1. Динамическая имитационная модель механизма конкурентного взаимодействия на кредитном рынке

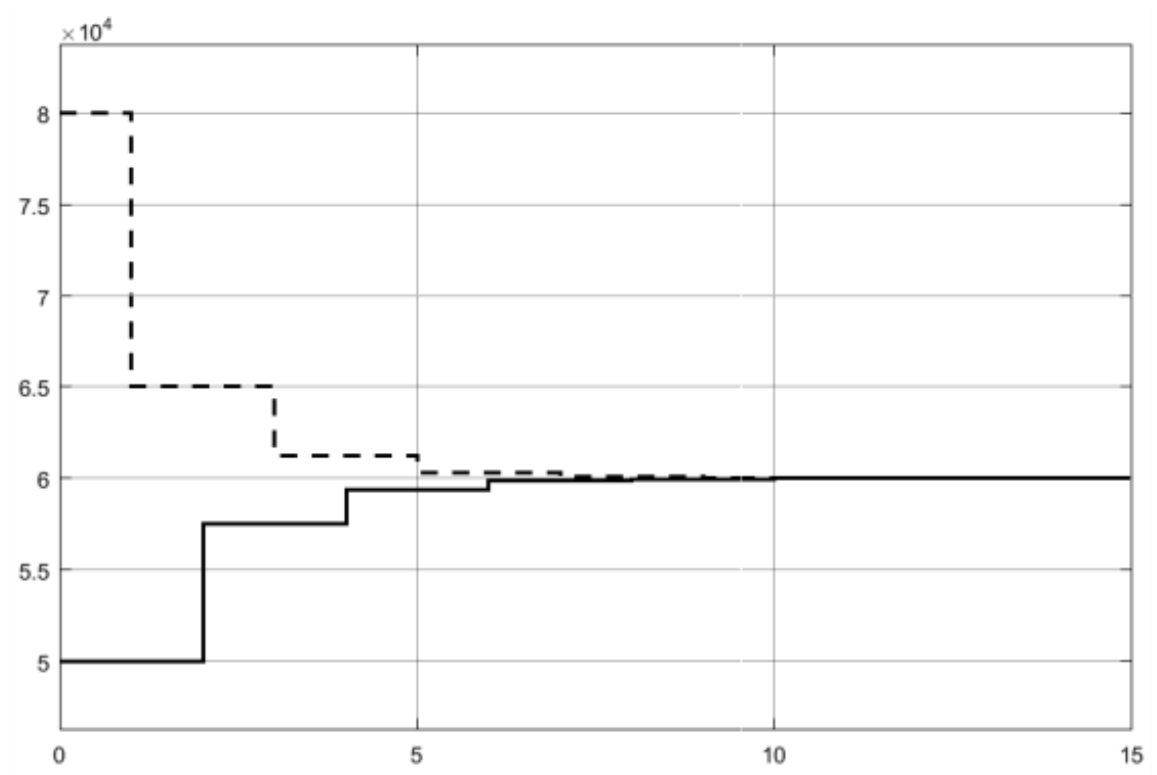

Рuc. 2. Траектории изменения объемов кредитования 
банками в равных долях. Подставляя значения объемов кредитования $Y_{1}(t), Y_{2}(t)$, в обратную функцию спроса $\alpha(t)=\alpha_{0}-b\left(Y_{1}(t)+Y_{2}(t)\right)$ определим траекторию изменения процентной ставки кредитования. Для этого сформирована на рис. 3. динамическая имитационная модель, решение которой позволяет определить траекторию изменения процентной ставки кредита в процессе конкурентного взаимодействия между банками.

На рис. 4. представлена траектория измене- ния процентной ставки в процессе рыночного взаимодействия банков. Как следует из полученной модели траектория процентной ставки кредита достигает равновесного значения равного $\alpha^{P}=6 \%$ годовых.

Из динамической имитационной модели, представленной на рис. 3., определим траекторию изменения суммарного объема кредитования, изображенной на рис. 5. Величина суммарного объема уменьшается с начального объема кредитования равного $Y_{1}(0)+Y_{2}(0)=1,3^{*} 10^{5}$ д.ед.

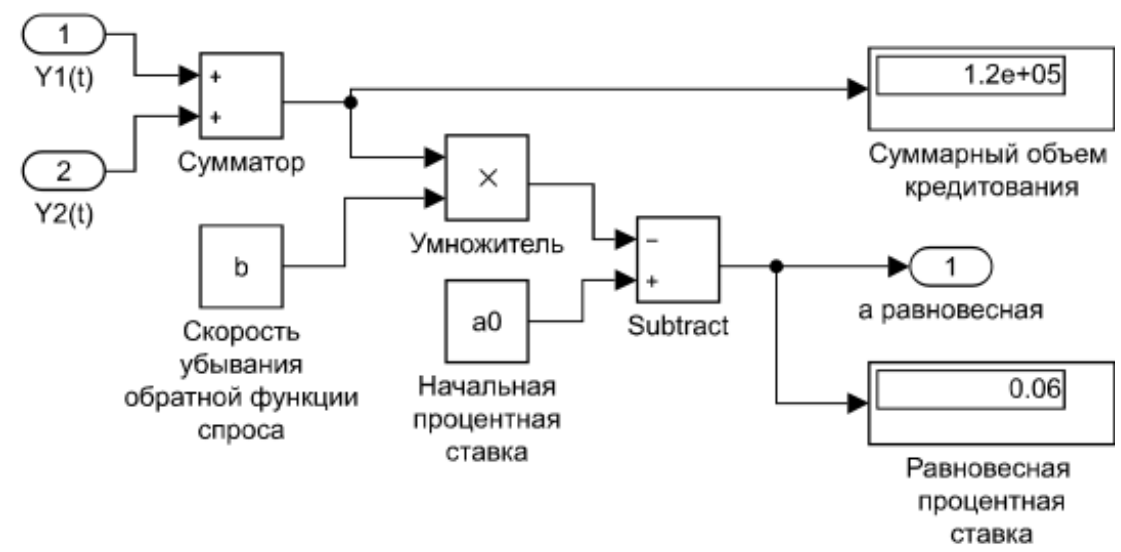

Рис. 3. Динамическая имитационная модель формирования процентной ставки

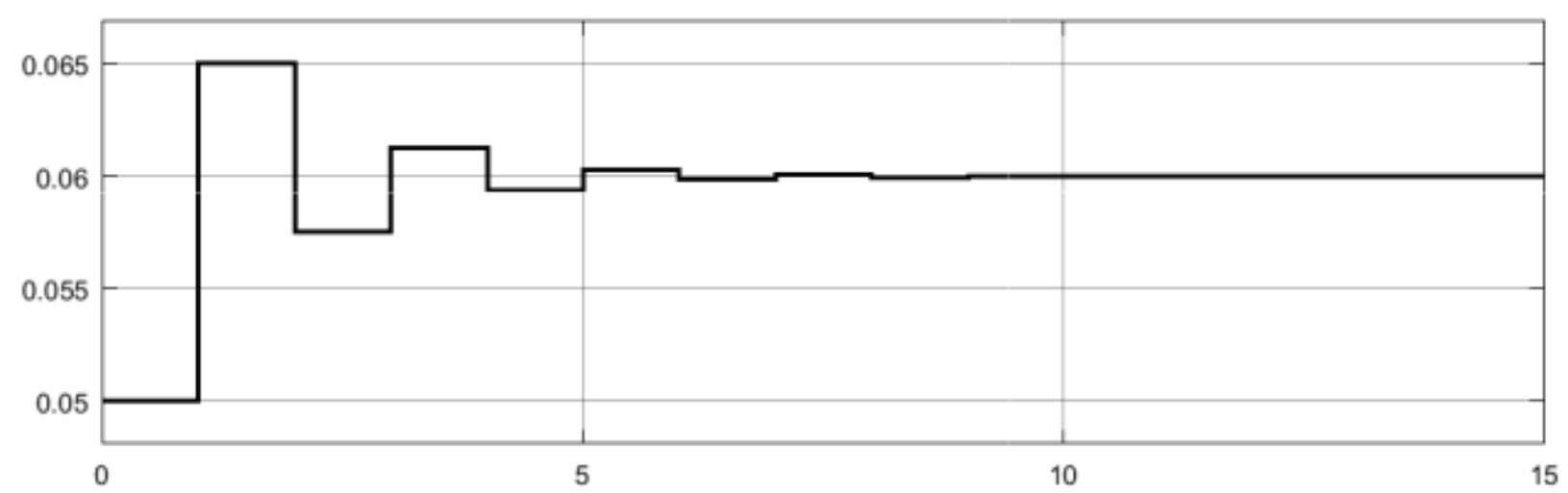

Puc. 4. Траектория изменения процентной ставки кредита

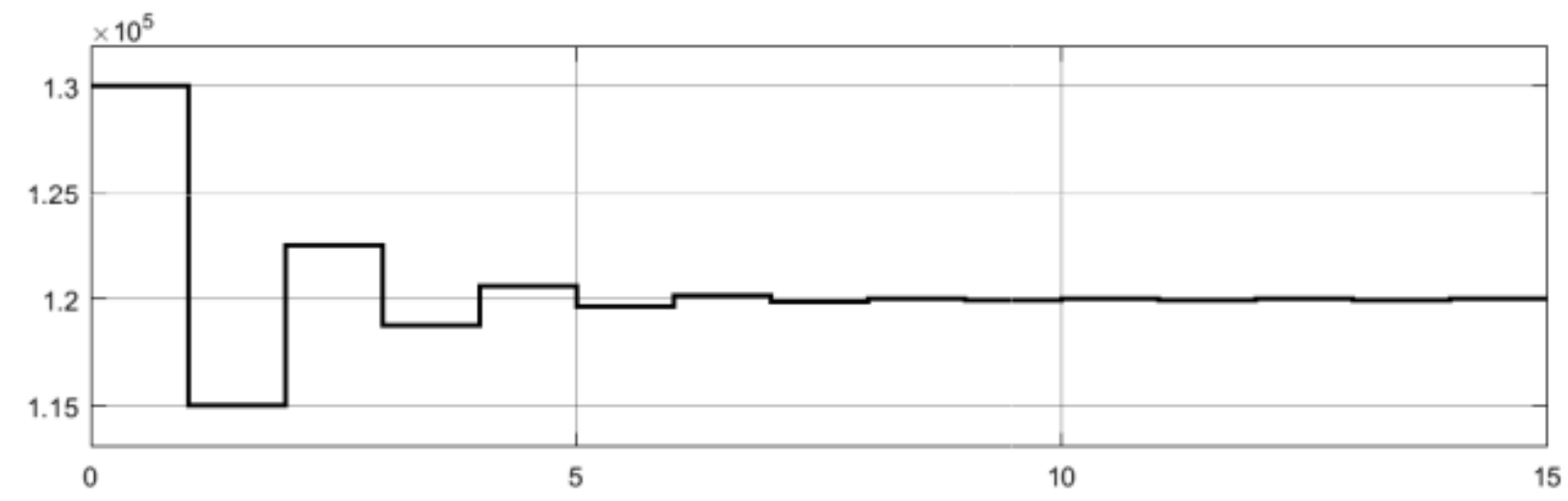

Рис. 5. Траектория изменения суммарного объема кредитования 
и достигает равновесного значения $Y^{P}(t)=$ $1,2 * 10^{5}$ д.ед.

Для определения операционного дохода, получаемого каждым банком от реализации кредитов, сформирована имитационная модель, представленная на рис. 6. Входными данными имитационной модели являются объемы кредитования первым, вторым банком и процентная ставка кредитов, динамика изменения которых проявляется в процессе конкурентного взаимодействия.

На рис. 7. изображены траектории изменения объема процентного дохода получаемого каждым банком от реализации кредитов. Процентный доход первого банка возрастает (сплошная линия), а второго (пунктирная линия) - уменьшается от начального условия с каждой итерацией и достигает равновесного значения равного ПД ${ }_{1}(t)=\Pi_{2}{ }^{P}(t)=3600$ д.ед. Равенство равновесных значений процентных доходов объясняется тем, что процентная ставка кредита и объемы кредитования в состоянии равновесия равны соответственно между собой.

Рассмотрим дискретную динамическую модель задачи выбора конкурентных стратегий на кредитном рынке с учетом затрат на покупку денежных ресурсов на депозитном рынке, расходов на привлечение денежных ресурсов и вовлечения их в кредиты, формирования резервных фондов и др. в следующем виде:

$$
\left\{\begin{array}{l}
Y_{1}(t+1)=\frac{\alpha_{0}-Z_{1}}{2 b}-\frac{1}{2} Y_{2}(t), \\
Y_{2}(t+1)=\frac{\alpha_{0}-Z_{2}}{2 b}-\frac{1}{2} Y_{1}(t) .
\end{array}\right.
$$

где $Z_{i}$ - приведенное к объему кредитования удельные затраты.

Для решения полученной дискретной динамической системы уравнений (4) сформируем имитационную динамическую модель, изобра-

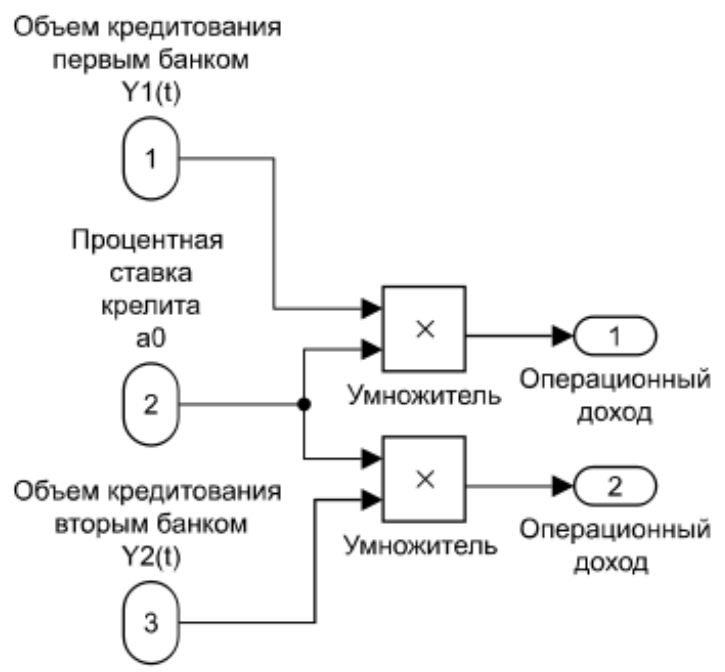

Puc. 6. Динамическая имитационная модель формирования операционного дохода, получаемого каждым банком

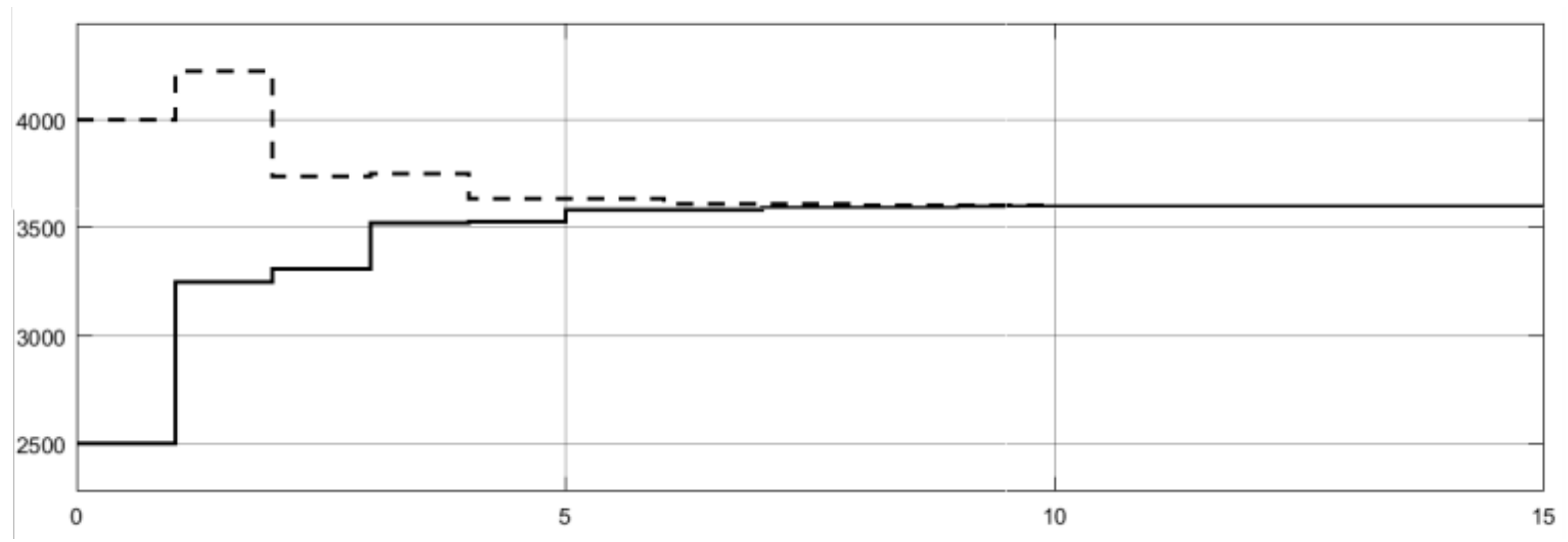

Puc. 7. Траектории изменения объема процентного дохода получаемого каждым банком от реализации кредитов 
женную на рис. 8. при следующих заданных исходных данных:

$\alpha_{0}=18 \%$ годовых; $b=1$ * $10^{-6}$ д.ед.;

$Y_{1}(0)=5^{*} 10^{4}$ д.ед.; $Y_{1}(0)=8 * 10^{4}$ д.ед;

$Z_{1}=0,4 \% ; Z_{2}=0,8 \%$.

Отличительной особенностью полученной динамической дискретной имитационной модели от изображенной на рис. 1. является то, что в модели присутствуют, в качестве входного сигнала, удельные затраты, связанные с реализацией кредитов каждым банком $Z_{1}$ и $Z_{2}$.

С учетом исходных данных на рис. 9. определены траектории изменения объемов кредитования $Y_{1}(t)$ и $Y_{2}(t)$ каждым банком в процессе конкурентного взаимодействия. Из полученных графиков следует, что траектории изменения объемов кредитования достигают различных по величине равновесных объемов кредитования $Y_{1}{ }^{P}(t)=6^{*} 10^{4}$ д.ед. и $Y_{2}{ }^{P}(t)=2 * 10^{4}$ д.ед. Траекто- рия изменения объема кредитования первого банка достигает равновесного значения большего по величине, чем у второго $Y_{1}{ }^{P}(t)>Y_{2}{ }^{P}(t)$. Это объясняется тем, что удельные затраты первого банка меньше чем у второго $Z_{1}<Z_{2}$, это обеспечивает ему конкурентное преимущество по затратам, относительно второго банка и увеличивает его возможности по увеличению кредитования на финансовом рынке.

Траектория изменения процентной ставки кредитования, представленной на рис. 10., определена с использованием динамической модели, изображенной на рис. 3. Из рисунка следует, что равновесная процентная ставка, с учетом удельных затрат на реализацию кредитов повысилась и стала равной $\alpha^{P}=10 \%$ годовых.

Из динамической имитационной модели представленной на рис. 3. определим траекторию изменения суммарного объема кредитова-

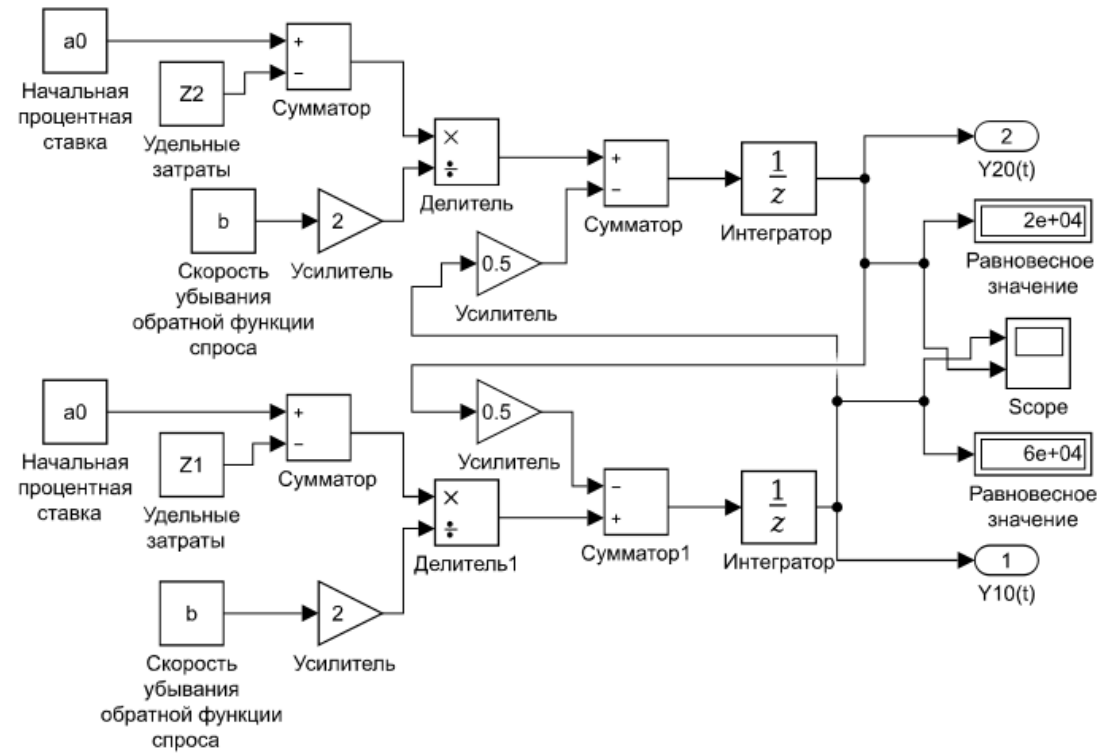

Puc. 8.Имитационная модель финансового механизма конкурентного взаимодействия между банками на кредитном рынке

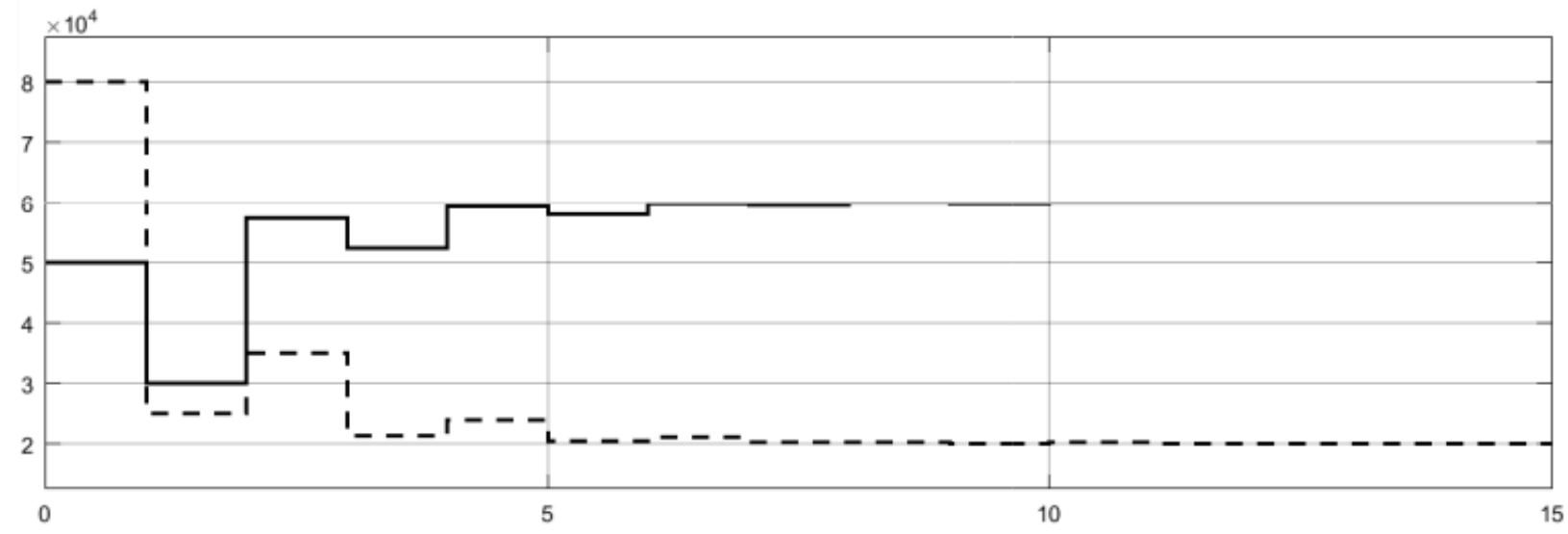

Puc. 9. Траектории изменения объемов кредитования и каждым банком 
ния, с учетом удельных затрат на реализацию кредитов, изображенной на рис. 11. Величина суммарного объема уменьшается с начального объема кредитования равного $Y_{1}(0)+Y_{2}(0)=$ $1,3^{*} 10^{5}$ д.ед. и достигает равновесного значения $Y^{P}(t)=8^{*} 10^{4}$ д.ед. Полученное равновесное значение суммарного объема кредитования меньше величины кредитования, полученного в ситуации отсутствия удельных затрат на реализацию кредитов, равного $1,2 * 10^{5}$ д.ед.
На рис. 12. изображены траектории изменения объема процентного дохода получаемого каждым банком от реализации кредитов, с учетом удельных затрат на реализацию кредитов, рассчитанной по динамической имитационной модели, представленной на рис. 6. Процентный доход первого банка возрастает (сплошная линия), а второго (пунктирная линия) - уменьшается от начального условия с каждой итерацией и достигает равновесных значений равных

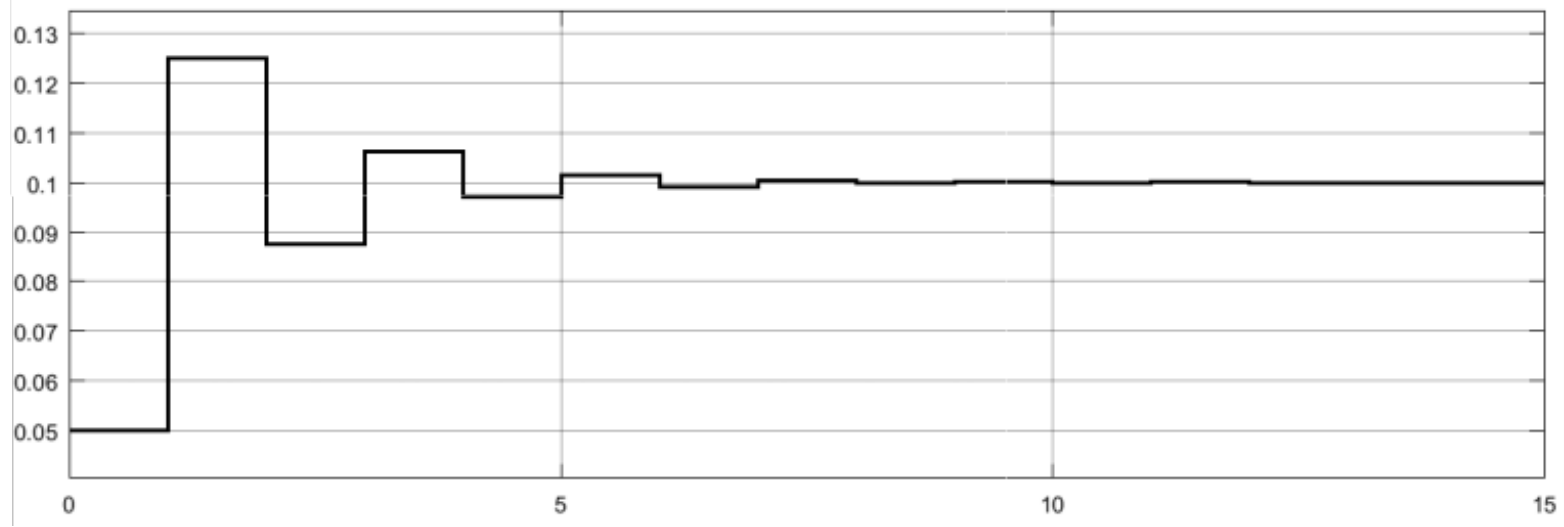

Рис. 10. Траектория изменения процентной ставки кредитования с учетом удельных затрат

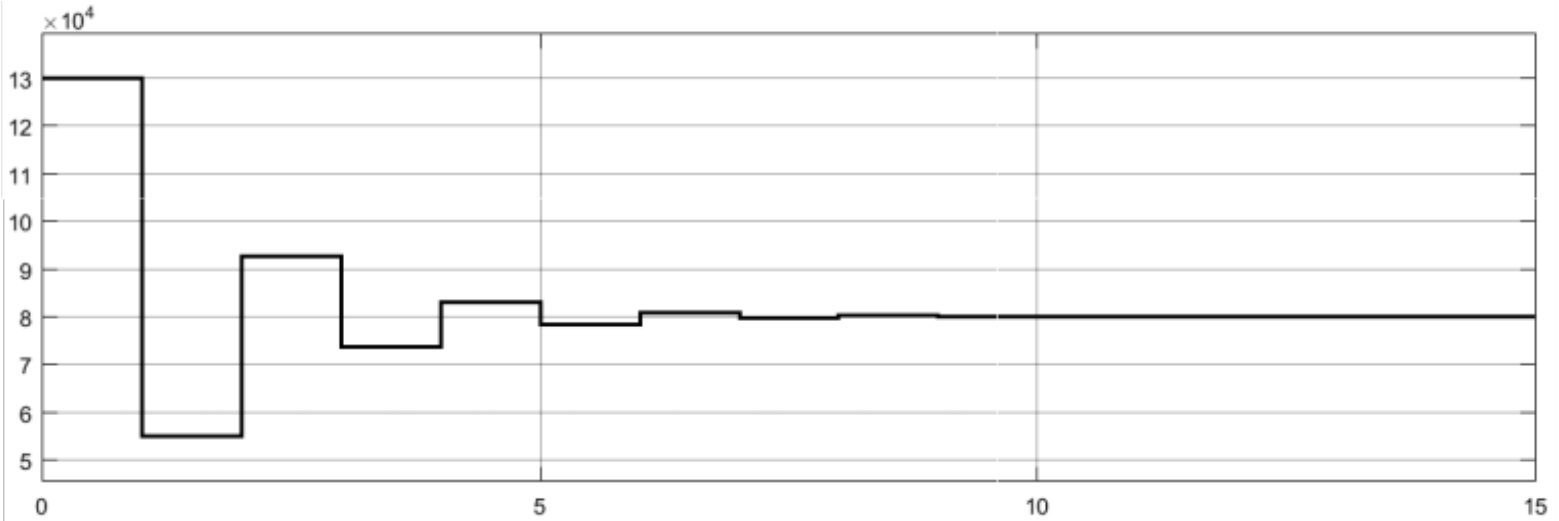

Puc. 11. Траектория изменения суммарного объема кредитования

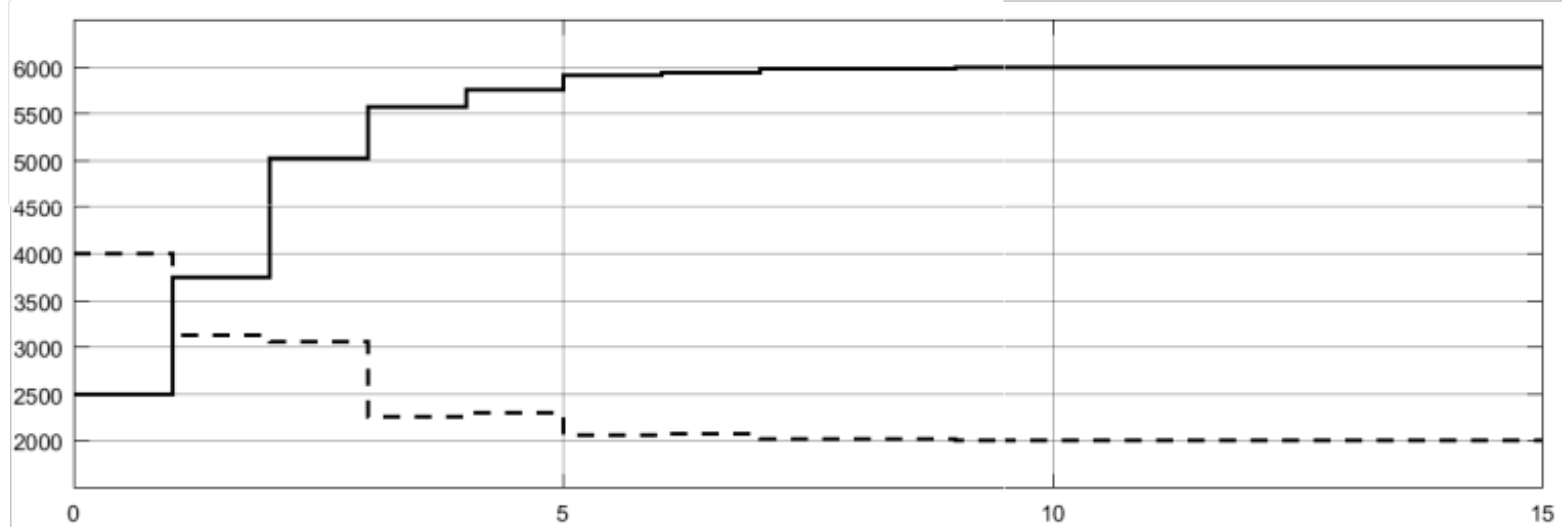

Puc. 12. Траектории изменения объема процентного дохода получаемого каждым банком 
ПД ${ }_{1}{ }(t)=6000$ д.ед. и ПД ${ }_{2}{ }^{P}(t)=2000$ д.ед.

Различие по величине равновесных объемов процентного дохода, получаемого каждым банком, объясняется разницей по величине удельных затрат на реализацию кредитов. Банк, у которого меньше удельные затраты, получает больший процентный доход в связи с увеличением возможностей по кредитованию на финансовом рынке.

Таким образом, проведенные расчеты по ди- намической имитационной модели позволяют обосновать динамику изменения параметров финансового механизма конкурентного взаимодействия и дать оценку равновесному состоянию по объему кредитования каждого банка $Y_{1}^{P}(t)$ и $Y_{2}^{P}(t)$, равновесной процентной ставке кредитования $\alpha^{P}$, суммарному равновесному объему кредитования $Y^{P}(t)$ и объемам процентного дохода, получаемого каждым банком от реализации кредитов ПД ${ }_{1}{ }^{P}(t)$ и ПД ${ }_{2}{ }^{P}(t)$.

\section{Библиографический список}

1. Сорокина М.Г., Гришанова А.Д., Клентак Л.С. Формирование механизмов конкурентного взаимодействия между коммерческими банками на кредитном рынке // Известия Самарского научного центра Российской академии наук, т. 15, № 6(3), 2013 с. 812-813.

2. Сорокина М.Г., Ежов С.Е., Гришанова А.Д. Формирование устойчивых стратегий банками в условиях объемной и ценовой конкуренции на финансовом рынке // Экономические науки 10(95) 2012 г.с. 163-168.

3. Черных И.В. «Simulink: Инструмент моделирования динамических систем» // http://matlab.exponenta.ru/ simulink/book1. 


\title{
ИПОТЕЧНОЕ ЖИЛИЩНОЕ КРЕДИТОВАНИЕ: ОСОБЕННОСТИ ФОРМИРОВАНИЯ И РАЗВИТИЯ
}

\author{
(c) 2018 Борлакова Татьяна Евгеньевна \\ преподаватель кафедры Финансы и кредит \\ Самарский государственный экономический университет \\ 443090, г. Самара, ул. Советской Армии, д. 141 \\ E-mail: borlakova@bk.ru
}

Одним из важнейших признаков самодостаточности нации и ее культуры выступают уровень обеспеченности граждан доступным и комфортным жильем. Для современной России это рассматривается в качестве одного из приоритетных направлений ее развития. В число основных экономических и социально-значимых проблем также входят оживление жилищного рынка посредством развития ипотечного жилищного кредитования и увеличения объемов жилищного строительства.

Ключевые слова: ипотечное жилищное кредитование, заемщики, кредиторы, операторы вторичного рынка, оценочные, страховые и риэлтерские компании, государственные регистрирующие органы, инвесторы.

В этой связи поддержание устойчивого экономического роста, формирование конкурентоспособной экономики, направленных на повышение инвестиционной активности и нормализация финансового сектора остаются важнейшими направлениями социально-экономического развития страны.

Ипотечное кредитование выступает неотъемлемым элементом рыночной экономики. По своей сути он представляет собой особую форму экономических отношений, заключающихся в предоставлении кредитных средств под залог недвижимого имущества. Значимость ипотечного жилищного кредитования заключается в его способности решать жилищные проблемы населения. Одновременно решаются и другие существенные вопросы: развитие ипотечного жилищного кредитования способствует снижению инфляционных процессов, формированию конкурентоспособной экономики и снижению социальной атмосферы в обществе.

Уровень развития ипотечного жилищного кредитования в стране принято сравнивать с величиной валового внутреннего продукта. Рассматривая этот показатель в сравнении с другими странами, необходимо отметить, что величина этого показателя существенно отстает от уровня других стран. Так, в странах Европейского союза он составляет около 50\%, в США - более $70 \%$, в России - не превышает 3-х процентов. В этой связи ипотечному жилищному кредитованию уделяется значительное внимание в проводимой государственной политике, направ-

ленной на обеспечении населения доступным и комфортным жильем.

Ипотечный жилищный кредит предоставляется в денежной форме или в форме ипотечных облигаций под залог объекта недвижимости с целью покупки (строительства) данной недвижимости. Особенность ипотечного кредита, также как и других форм кредитных отношений, заключается в его строго целевом использовании, т.е. приобретении или строительстве недвижимости.

Также следует отметить, что ипотечный кредит представляет собой движение ссудного капитала в сфере недвижимости, связанное с предоставлением денежных ресурсов на условиях возвратности, срочности и платности.

Ипотечный кредит развивается при следующих условиях:

- требования кредитора обеспечены недвижимым имуществом;

- ипотечный кредит возникает только тогда, когда залогодатель обладает предметом ипотеки на правах частной собственности;

- ипотечный кредит носит долгосрочный характер;

- выдаваемая ссуда значительна по своей величине;

- залог остаётся в руках заемщика до окончания срока кредитного договора.

Таким образом, ипотечное кредитование представляет собой одну из форм кредитных отношений, при которых закладываемое имущество остается в собственности заемщика, а 
кредитор в случае невозможности взыскания долга может обеспечить возврат кредита за счет продажи заложенного имущества.

В различных источниках определение «ипотечное жилищное кредитование» трактуется по-разному. При всём многообразии представленных подходов к определению ипотечного кредитования, в каждом из них он трактуется по-разному. Ипотечное кредитование - это совокупность экономико-правовых отношений, сопровождающих приобретение, строительство и реконструкцию объектов недвижимого имущества посредством долгосрочных займов под залог недвижимости [1]. О.И. Лаврушин рассматривает кредит как передачу кредитором ссуженной стоимости заемщику для использования на началах возвратности и в интересах общественных потребностей [2].

Г.Н. Белоглазова дает следующее определение понятию кредит. Кредит как экономическая категория представляет собой определенный вид общественных отношений, связанных с движением стоимости на условиях возвратности [3]. Согласно В.П. Герасименко «Финансы и кредит», кредит - это движение ссудного капитала, то есть денежного капитала, предоставляемого в ссуду на условиях возврата за плату в виде процента. Это стоимостная экономическая категория, неотъемлемый элемент товарно-денежных отношений [4].

Таким образом, труды рассмотренных авторов позволяют дать следующее определение кредиту как экономической категории: кредит - это форма движения ссудного капитала и его перераспределение на условиях возвратности, срочности и платности.

Следует отметить, что кредитные организации заинтересованы в развитии ипотечного кредитования, что объясняется возможностью долгосрочного и надежного вложения финансовых ресурсов, в первую очередь в кредитование строительства жилья, а также в формирование долгосрочной клиентской базы.

Ипотечное жилищное кредитование чаще всего рассматривается как целая система, поскольку оно включает значительное число участников, их взаимосвязей, в связи, с чем выходит за рамки отношений «кредитор-заемщик». В эту систему включаются элементы правового регулирования, государственной поддержки, рефинансирования, что отличает ипотечное кредитование от других видов потребительского кредитования. К таким элементам относятся: заемщики, кредиторы, операторы вторичного рынка, оценочные, страховые, риэлтерские компании, государственные регистрирующие органы, инвесторы.

Помимо непосредственных участников в системе ипотечного жилищного кредитования важное место занимают инфраструктурные звенья. К ним относятся: нотариат, паспортные службы, органы опеки и попечительства, юридические консультации и т.д. Основными функциями инфраструктурных звеньев являются:

а) обеспечение необходимого юридического сопровождения сделок с жилыми помещениями;

б) регистрация граждан по месту жительства,

в) защита прав несовершеннолетних при заключении сделок с недвижимостью.

Следует отметить, что особое место, в первую очередь на начальном этапе создания системы долгосрочного ипотечного жилищного кредитования, занимает государство. Оно выполняет следующие основополагающие для развития ипотечного жилищного кредитования функции:

1) определяет концепцию развития ипотечного жилищного кредитования;

2) формирует законодательные и правовые условия для всех участников ипотечного жилищного кредитования в целях надежного и эффективного функционирования системы ипотечного кредитования;

3) создает механизмы социальной защиты заемщиков в первую очередь тех, которые не могут участвовать в кредитной сделке на общих основаниях;

4) обеспечивает налоговый режим наибольшего благоприятствования для участников рынка ипотечного кредитования с целью повышения доступности ипотечных кредитов населению;

5) предоставляет гарантии инвесторам по средствам, привлекаемым Агентством по ипотечному жилищному кредитованию для выпуска ипотечных ценных бумаг.

Система ипотечного жилищного кредитования включает пять сегментов, тесно взаимосвязанных и взаимообусловленных. Это:

1. Первичный рынок ипотечных кредитов, на котором основные участники - кредиторы и заемщики вступают в кредитную сделку.

2. Вторичный рынок ипотечного креди- 
тования, на котором формируются отношения кредитора и заемщика в процессе уступки кредитных требований, а также операторов вторичного рынка, выпускающих ипотечные ценные бумаги для привлечения финансовых ресурсов первичному кредитору.

3. Рынок ценных бумаг, который генерирует денежные ресурсы для развития ипотечного жилищного кредитования.

4. Рынок недвижимости, на котором формируется спрос и предложение, удовлетворяющие потребность населения в поиске жилого объекта и удовлетворяющие его предпочтения.

5. Страховой рынок, функциональным назначением которого выступает страхование рисков в системе ипотечного жилищного кредитования.

Неотъемлемым элементом ипотечного кредитования является обеспечение кредита. Оно является своего рода гарантией его возврата. Это обусловливает особую значимость механизма обеспечения кредита, поскольку возвратность рассматривается как основополагающее свойство кредитных отношений.

Изначально возвратность кредита обеспечивается регулярным получением дохода заемщиком - это первичный источник погашения. Но банку необходим вторичный источник погашения кредита. Это связано с риском несвоевременного получения или неполучения дохода заемщиком. В ипотечном жилищном кредитовании вторичным источником погашения кредита является залог приобретаемой квартиры. При этом в случае неисполнения (ненадлежащего исполнения) заемщиком своих обязательств по кредитному требованию, банк имеет право обратить взыскание на заложенную недвижимость и получить удовлетворение своих претензий из стоимости, полученной от реализации предмета залога.
Рынок ипотечного кредитования является связующим звеном между рынком недвижимости и кредитным рынком с одной стороны, с другой между кредитным рынком и фондовым рынком. Первичный и вторичный ипотечные рынки обеспечивают полноценный жизненный цикл ипотечного кредита. Их взаимосвязь проявляется в том, что недостаточная степень развития вторичного рынка сдерживает увеличение кредитных операций на первичном рынке и наоборот, формирование полноценного вторичного рынка увеличивает объемы кредитных операций на первичном рынке.

Развитие ипотечного жилищного кредитования за последние годы характеризовалось следующими особенностями. В первую очередь необходимо отметить сокращение банков, предоставляющих ипотечные жилищные кредиты. Так, по сравнению с первым полугодием 2017 года количество банков, осуществляющих ипотечное жилищное кредитование, за аналогичный период 2016 года, сократилось на 30 кредитных организаций, а на начало 2018 г.- еще на 24 кредитных организации и составило 460 единиц.

Вместе с тем наблюдается увеличение объема предоставляемых ипотечных кредитов. Так, в первые месяцы 2017 года объем кредитования увеличился на $16,3 \%$ по сравнению с аналогичным периодом 2016 года и превысил показатель соответствующего периода рекордного по объемам 2014 года.

Вместе с тем современная геополитическая обстановка и ухудшение внешнеэкономических условий в РФ обусловливают снижение уровня жизни населения и его возможности в своевременном погашении задолженности по ипотечному кредиту (табл. 1).

По представленным данным можно сделать вывод о достаточно высоких темпах развития

Таблиц̧ 1. Динамика задолженности по ипотечным кредитам в России к ВВП

\begin{tabular}{|c|c|c|c|c|c|}
\hline \multirow{2}{*}{ Дата } & \multicolumn{3}{|c|}{ ВВП } & \multicolumn{2}{|c|}{ Задолженность по ипотечному кредиту } \\
\cline { 2 - 6 } & млрд. руб. & Темп роста, \% & млн. руб. & Темп роста, \% & Доля в ВВП, \% \\
\hline 01.01 .2013 & 62147 & 100,0 & 1997204 & 100,0 & 3,2 \\
\hline 01.01 .2014 & 66194 & 106,5 & 2648859 & 132,6 & 4,1 \\
\hline 01.01 .2015 & 77893 & 117,7 & 3528379 & 133,2 & 4,5 \\
\hline 01.01 .2016 & 80413 & 103,2 & 3920442 & 111,1 & 4,9 \\
\hline 01.01 .2017 & 85881 & 105,5 & 4493155 & 114,6 & 5,2 \\
\hline 01.01 .2018 & 92082 & 107,2 & 5187462 & 115,4 & 5,6 \\
\hline
\end{tabular}

Источник. Рассчитано по данным официальных сайтов Федеральной службы государственной статистики и Агентства по ипотечного жилищного кредитования. 
ипотечного жилищного кредитования. Общая задолженность заемщиков перед банками увеличилась в 2,6 раза, а доля задолженности в ВВП России увеличилась почти в 2 раза и достигла 5,6\%. Вместе с тем необходимо отметить, что Всемирным банком для стран среднего уровня развития данный показатель установлен в размере $25 \%$ и Россия существенно отстает от развитых стран по уровню обеспечения граждан доступным и комфортным жильем, что в решающей степени обусловлено дефицитом долгосрочных и относительно дешевых финансовых ресурсов.

Одним из важнейших вопросов успешного развития ипотечного жилищного кредитования является формирование долгосрочных ресурсов.

Чтобы преодолеть дефицит ресурсов, банки используют различные инструменты рефинансирования. Основным методом рефинансирования выступает секьюритизация. Секьюритизация представляет собой финансовую операцию, обеспечивающую поступление денежных средств на основе трансформации низколиквидных активов в ипотечные ценные бумаги. Ипотечный кредит относится к числу таких низколиквидных активов [5].

Эмиссия ипотечных ценных бумаг и формирование сквозного потока платежей, как источника формирования покрытия у банка-отригинатора, являются основополагающими характеристиками секьюритизации. Практика показывает, что на ее основе осуществляется наибольший объем эмиссии ипотечных ценных бумаг, что подтверждает ее востребованность, как модели привлечения финансовых ресурсов. Вместе с тем, необходимо отметить, что в настоящее время объемы сделок секьюритизации в России имеют незначительные объемы и существенно отстают от развитых стран (табл. 2).
По данным табл. 2 видно, что объемы эмиссии ипотечных ценных бумаг занимают незначительную долю в объемах ипотечного кредитования и находятся в интервале 5,5-14,5 процентов. В настоящее время банки осуществляют только внутреннюю секьюритизацию. Она доступна лишь крупным банкам, которые в основном являются участниками государственных программ.

В целях повышения эффективности развития ипотечного жилищного кредитования в России и формирования его ресурсной базы Государственным советом по вопросам развития строительного комплекса и совершенствования градостроительной деятельности 17 мая 2016 года была создана «Фабрика ИЦБ» (ипотечных ценных бумаг). Функционально она выступает инструментом привлечения финансирования на рынок ипотечного жилищного кредитования, и как следствие, увеличения объемов кредитования. Первая сделка секьюритизации ипотечного портфеля на программной основе в рамках нового механизма рефинансирования ипотечного жилищного кредитования была проведена Сбербанком.

Можно выделить следующие преимущества выпуска облигаций по программе «Фабрика ИЦБ»:

1) Банк России включает ИЦБ в ломбардный список, что позволяет. инвесторам привлечь необходимую ликвидность;

2) соответствуют требованиям высшего котировального списка Московской биржи в результате поручительства Агентства по ипотечному жилищному кредитованию;

3) высокая степень надежности обеспечивает рыночный уровень доходности;

4) при выпуске ИЦБ Оригинатор не несет рисков дефолта портфеля ипотечных кредитов;

Таблица 2. Соотношение объемов выдачи ипотечных жилищных кредитов и выпуска ипотечных ценных бумаг (секьюритизации) в России

\begin{tabular}{|c|c|c|c|c|c|}
\hline \multirow{2}{*}{ Год } & \multicolumn{2}{|c|}{$\begin{array}{c}\text { Объем выданных ипотечных креди- } \\
\text { тов }\end{array}$} & \multicolumn{2}{|c|}{$\begin{array}{c}\text { Объем выпуска ипотечных ценных } \\
\text { бумаг }\end{array}$} & \multirow{2}{*}{$\begin{array}{c}\text { Соотношение } \\
\text { объемов выпуска } \\
\text { ценных бумаг и } \\
\text { выдачи ипотеч- } \\
\text { ных кредитов, \% }\end{array}$} \\
\hline & Млрд руб. & $\begin{array}{l}\text { Темп роста к пре- } \\
\text { дыдущем году, \% }\end{array}$ & Млрд руб. & $\begin{array}{l}\text { Темп роста к пре- } \\
\text { дыдущему году, \% }\end{array}$ & \\
\hline 2013 & 1354 & 110,0 & 145 & 100,0 & 10,7 \\
\hline 2014 & 1764 & 130,3 & 256 & 176,6 & 14,5 \\
\hline 2015 & 1162 & 65,9 & 64 & 25,0 & 5,5 \\
\hline 2016 & 1473 & 126,8 & 81 & 126,6 & 5,5 \\
\hline 2017 & 2032 & 137,9 & 124 & 153,1 & 6,1 \\
\hline
\end{tabular}

Источник. Рассчитано по данным Банка России и Агентства по ипотечному жилищному кредитованию (АИЖК) 
5) при расчете обязательных банковских нормативов ипотечные ценные бумаги взвешиваются с коэффициентом 20;

6) проблем с взвешиванием младших траншей на балансе банка не возникает;
Таким образом, сложность ипотечного жилищного кредитования как наиболее сложной формы кредитных отношений требует государственного участия в его развитии.

\section{Библиографический список}

1. Ипотека: 100 вопросов и ответов / Симионов Ю.Ф., Далаксакуашвили И.Д., Ясько В.Л., Ясько Л.В. Ростов на Дону. 2006. С. 134.

2. Лаврушин О.И. Банковское дело: современная система кредитования / О.И. Лаврушин, О.Н. Афанасьева. Москва. 2013. 360с.

3. Белоглазова Г.Н. Деньги, кредит, банки. Москва. 2014. 254c.

4. Герасименко В.П. Финансы и кредит / В.П. Герасименко, Е.Н. Рудская. Москва. 2013. 199с.

5. Савинова В.А., Самсуни А.Ю. Теоретические основы ипотечного жилищного кредитования и современная практика его развития в России // Экономические науки. 2017. № . 4 (149). С. 85.

Поступила в редакцию 25.08.2018 


\section{ECONOMICS AND SOCIOLOGY}

№3 (39)

2018 


\section{CONTENTS}

\section{SOCIOLOGY}

\section{THEORY, METHODOLOGY AND HISTORY OF SOCIOLOGY}

Gyul D.V. Turkish sociology: the main stages of the development

\section{SOCIAL STRUCTURE, SOCIAL INSTITUTIONS AND PROCESS}

Khodykin A.V. Problems and prospects of labor development in the context of the transition to a green economy

\section{ECONOMY. ECONOMIC SCIENCE}

\section{ECONOMIC THEORY}

Ryazanova O.E. Property relations in the social sphere: institutional approach 65

Ermolaev K.N. Methodological significance of the Marxist concept of fictitious capital to analyze the present stage of development of the global capital

\section{ECONOMICS AND MANAGEMENT OF NATIONAL ECONOMY}

Plotkin B.K., Sosunova L.A. From material and technical supply to logistics and back 66

Sobolev E.N. Human capital in the system of wage remuneration factors for skilled labor

\section{FINANCE, MONEY CIRCULATION AND CREDIT}

Sorokina M.G. Formation of dynamic simulation models of financial mechanisms for competitive interaction between banks in the credit market 67

Borlakova T.E. Mortgage housing loans: features of formation and development 67 


\title{
SOCIOLOGY
}

\section{THEORY, METHODOLOGY AND HISTORY OF SOCIOLOGY}

\section{TURKISH SOCIOLOGY: THE MAIN STAGES OF THE DEVELOPMENT}

\author{
(C) 2018 Gyul DaryaVladimirovna \\ Candidate of Historical Sciences, Associate Professor \\ Associate Professor of the Department of Methodology of Sociological \\ Faculty of Sociology and Marketing Research \\ Samara National Research University named after S.P. Korolev \\ 1, Akademika Pavlov Street, Samara, 443011, Russia \\ E-mail:fisa-f@mail.ru
}

The article covers the area of history of sociology in Turkey. Its key idea is to introduce the main periodization of sociology in Turkey worked out by the leading Turkish sociologists. A system approach used in the research allows having an idea of the influence of different factors on the development of sociology in Turkey. The main events which have become turning points in the history of the science development and the main names of sociologists and spheres of their interests are introduced.

Key words: history of sociology, sociology in Turkey, history of Turkish sociology, periods of the development of Turkish sociology, Turkish sociologists.

\section{SOCIAL STRUCTURE, SOCIAL INSTITUTIONS AND PROCESS}

\section{PROBLEMS AND PROSPECTS OF LABOR DEVELOPMENT IN THE CONTEXT OF THE TRANSITION TO A GREEN ECONOMY}

\author{
(c) 2018 Khodykin Alexander Vladimirovich \\ Samara National Research University named after S.P. Korolev \\ 1, Akademika Pavlov Street, Samara, 443011, Russia \\ E-mail: avhod@yandex.ru
}

The article studies the environmental, economic and social aspects of the global transition to a green economy declared at the international level. On the basis of international documents author analyzed the problems and prospects of development of the labor sphere in the context of the global transition to a green economy.

Key words: green economy, labor market, environment, development, problems, prospects, international community, green workplace.

\section{References}

1. Living Planet Report / Doklad Vsemirnogo fonda prirody` o Zhivoj planete. - 2010. [E`lektronny`j resurs]. - URL: http://www.wwf.ru/recources/publ/book/436 (data obrashheniya: 10.10.2018).

[Living Planet Report / world wildlife Fund Report on a Living planet. - 2010. [Electronic resource.] - URL: http://www.wwf.ru/recources/publ/book/436 (date accessed: 10.10.2018).] 
2. Zaxarova T.V. «Zelyonaya» e`konomika kak novy`j kurs razvitiya: global`ny`j i regional`ny`j aspekty`// Vestnik Tomskogo gos. un-ta. E`konomika. - 2011. S. 28-38.

[Zakharova T. V. «Green» economy as a new course of development: global and regional aspects. Bulletin of Tomsk state University. Economy.- 2011. P. 28-38.]

3. Energy and Air Pollution:World Energy Outlook Special Report.Paris. - 2016. [Electronic resource]. - URL:www.iea. org/publications/freepublications/publication/WorldEnergyOutlookSpecial Report2016EnergyandAirPollution. pdf (Accessed 10.10.2018).

4. Green Jobs: Towards decent work in a sustainable, low-carbon world.UNEP, ILO, OIE, ITUC, 2008. - 2008. [Electronic resource].- URL: http://www.ilo.org/wcmsp5/groups/public/--ed_emp/--emp_ent/documents/publication/wcms_158727.pdf (Accessed 07.10.2018).

5. Vojkina E. A., Potravny ’ I.M. Zelenaya zanyatost` i ry`nok truda pri formirovanii e`kologicheski orientirovannoj e`konomiki // Vestnik Sankt-Peterburgskogo universiteta. E`konomika. - 2018. T. 34. Vy`p.2. S. 217-240. - 2018. [E`lektronny`j resurs]. - URL: https://doi.org/10.21638/11701/spbu05.2018.202 (data obrashheniya: 07.10.2018). [Vaskina E.A., Potravny I.M. Green's employment and labour market in the formation of the green economy // Vestnik of Saint Petersburg University. Economy.- 2018. Vol. 34. Vol.2. P. 217-240.- 2018. [Electronic resource.] - URL: https://doi.org/10.21638/11701/spbu05.2018.202 (date accessed: 07.10.2018).]

6. World Employment and Social Outlook 2018: Greening with jobs.- 2018. [Electronic resource].- URL: https://www.ilo.org/wcmsp5/groups/public/--dgreports/--dcomm/--publ/documents/publication/ wcms_628654.pdf (Accessed 07.10.2018).

7. Trifonov P.V. Zelyony`e rabochie mesta - osnova e`kologo-orientirovannoj e`konomiki v XXI veke // Strategii biznesa.-2015. № 3. S. 21-27.

[Trifonov P. V. Green jobs-the basis of eco-oriented economy in the XXI century // business Strategy. - 2015. No. 3 . P. 21-27.]

8. Human Development Indices and Indicators. Special Report.- 2018. [Electronic resource].- URL: http://hdr. undp.org/sites/default/files/2018_human_development_statistical_update.pdf (Accessed 07.10.2018).

9. Rejting stran mira po rejtingu e`kologicheskoj e`ffektivnosti: Yale Center for Environmental Law and Policy: The Environmental Performance Index 2018. - 2018. [E`lektronny`j resurs]. - URL: https://gtmarket.ru/ratings/ environmental-performance-index (data obrashheniya: 07.10.2018).

[World environmental performance rating: Yale Center for Environmental Law and Policy: the Environmental Performance Index 2018. - 2018. [Electronic resource.] - URL: https://gtmarket.ru/ratings/environmentalperformance-index (date accessed: 07.10.2018).]

10. Obzor mirovogo e`konomicheskogo i social’nogo polozheniya, 2014 god: sokrashhenie neravenstva $v$ interesax ustojchivogo razvitiya.- 2014. [E`lektronny`j resurs].- URL: http://www.un.org/en/development/desa/policy/ wess/wess_archive/2014wess_overview_ru.pdf (data obrashheniya: 10.10.2018).

[Review of world economic and social survey 2014: reducing inequality for sustainable development. - 2014 . [Electronic resource.] - URL: http://www.un.org/en/development/desa/policy/wess/wess_archive/2014wess_ overview_ru.pdf (date accessed: 10.10.2018).]

11. Statisticheskie danny`e OON: Gender Inequality Index. - 2018. [E`lektronny`j resurs]. - URL: http://hdr.undp.org/ en/composite/GII (data obrashheniya: 07.10.2018).

[Statistics UN data: Gender Inequality Index.- 2018. [Electronic resource.] - URL: http://hdr.undp.org/en/ composite/GII (date accessed: 07.10.2018).]

12. O vozobnovlyaemy`x istochnikax $v$ proizvodstve e`lektroe`nergii.- 2018. [E`lektronny`j resurs].- URL: https://ecotechnica.com.ua/energy/3349-dolya-vie-v-proizvodstve-elektroenergii-v-mire-dostigla-25.html (data obrashheniya: 07.10.2018).

[On renewable sources in the production of electricity. - 2018. [Electronic resource.] - URL: https://ecotechnica. com.ua/energy/3349-dolya-vie-v-proizvodstve-elektroenergii-v-mire-dostigla-25.html (date accessed: 07.10.2018).] 


\title{
ECONOMY.ECONOMIC SCIENCE
}

\section{ECONOMIC THEORY}

\section{PROPERTY RELATIONS IN THE SOCIAL SPHERE: INSTITUTIONAL APPROACH}

\author{
(C) 2018 Ryazanova Olesya Evgenevna \\ Doctor of Economics, Professor, Head of the Department of Economic Theory \\ Moscow State Institute of International Relations (University) \\ of the Ministry for Foreign Affairs of Russia (MGIMO) \\ 76, Vernadskogo pr., Moscow, 119454, Russia \\ E-mail: kafedra4006@mail.ru
}

The article notes that modern science is expanding the boundaries of the content "ownership". Putting forward the thesis that social benefits may be seen as "an abstract property" which cannot be subject to actual physical possession, but reducible to monetary evaluation, it is proved that they can use and dispose. It is shown that the property relations in the social sphere it is possible to allocate the benefit possession in order to benefit from "ownership" social benefits and burdens of the content in terms of costs to preserve their "ownership" and protect it from third parties. Concluded that the transaction type property relations in economic terms can appear through legal forms, that is probably the existence of property rights to social benefits. Due to the fact that social benefits may be the subject of alienation-attribution hypothesis on the existence of primary and derivative of property relations in the social sphere.

Key words: property relations, social sphere, entitlement to property, social benefits, transactions, transaction costs.

Received for publication on 10.08.2018

\section{METHODOLOGICAL SIGNIFICANCE OF THE MARXIST CONCEPT OF FICTITIOUS CAPITAL TO ANALYZE THE PRESENT STAGE OF DEVELOPMENT OF THE GLOBAL CAPITAL}

\author{
(C) 2018 Ermolaev Konstantin Nikolaevich \\ Doctor of Economics, Professor \\ Head of the Department of Institutional Economics and Economic History \\ Samara State University of Economics \\ 141, Soviet Army str., Samara, 443090, Russia \\ E-mail: ermolaevkn@yandex.ru
}

This article discusses methodological significance of the author's category «titular capital» to analyze the nature of fictitious capital and its virtualization, which is extremely important for the analysis of new phenomena and trends of development of the financial market post-industrial economy in the era of globalization.

Key words: capital title, capital property, the expected value of fictitious capital, fictitious value. 


\title{
ECONOMICS AND MANAGEMENT OF NATIONAL ECONOMY
}

\section{FROM MATERIAL AND TECHNICAL SUPPLY TO LOGISTICS AND BACK}

\author{
(C) 2018 Plotkin Boris Kalmanovich \\ Doctor of Economics, Professor \\ Industry Promotion Association. Scientific - economic committee \\ St. Petersburg \\ E-mail: kafedra-kl@yandex.ru \\ (c) 2018 Sosunova Liliana Alekseevna \\ Doctor of Economics, Professor \\ Samara State University of Economics \\ 443090, Samara, Sovetskoi Armii Street, 141 \\ E-mail:kafedra-kl@yandex.ru
}

The article deals with the following issues: the development of logistics, its interrelation with the material and technical supply, the presentation and knowledge of logistics; logistics as a supply chain; transport essence of logistics; cross - docking system.

Key words: logistics, material and technical supply, market economy, branch logistics, subject logistics, transport services, cross - docking

\section{HUMAN CAPITAL IN THE SYSTEM OF WAGE REMUNERATION FACTORS FOR SKILLED LABOR}

(c) 2018 Sobolev Eduard Nenjevich

Doctor of Economic Sciences, Leading Researcher

Institute of Economics of the Russian Academy of Sciences

32, Nakhimovsky prospect, Moscow, 117418

E-mail: edsobol@rambler.ru

The article examines the relationship between remuneration of skilled workers with their human capital. It is shown that in Russia, this relationship is weakly traced. A system of measures aimed at overcoming of wage remuneration bias based upon more comprehensive accounting for professional skills and educational attainment of workers forming their human capital stock is proposed.

Key words: human capital, labor remuneration, skilled labor, returns to education, wage differentiation. 
FINANCE, MONEY CIRCULATION AND CREDIT

\title{
FORMATION OF DYNAMIC SIMULATION MODELS OF FINANCIAL MECHANISMS FOR COMPETITIVE INTERACTION BETWEEN BANKS IN THE CREDIT MARKET
}

\author{
(C) 2018 Sorokina Marina Gennadievna \\ Doctor of Economics, Professor, Head of the Department of Finance and Credit \\ Samara National Research University named after S.P. Korolev \\ 34, Moscow highway, Samara, 443086, Russia \\ E-mail: ipoteka_sorokina@list.ru
}

The article developed discrete dynamic simulation models of the financial mechanism of competitive interaction between banks, allowing to determine the trajectory of changes in financial parameters and on this basis to justify the stability of the equilibrium states of the selected strategies in the credit market.

Key words: simulation model, competitive interaction mechanism, interest income, equilibrium state.

Received for publication on 09.09.2018

\section{MORTGAGE HOUSING LOANS: FEATURES OF FORMATION AND DEVELOPMENT}

\author{
(C) 2018 Borlakova Tatyana Evgenevna \\ Lecturer of the Department of Finance and Credit \\ Samara State University of Economics \\ 141, Soviet Army Street, Samara, 443090, Russia
}

One of the most important signs of the self-sufficiency of the nation and its culture is the level of provision of citizens with affordable and comfortable housing. For modern Russia, this is seen as one of the priority directions of its development. The number of basic economic and socially significant problems also includes the revitalization of the housing market through the development of mortgage housing loans and the increase in the volume of housing construction.

Key words: mortgage housing crediting, borrowers, creditors, secondary market operators, valuation, insurance and real estate companies, state registration bodies, investors 